\title{
Auto InSURAnCE As Social ConTract: SOLVING AUTOMOBILE INSURANCE COVERAGE DisPutes THROUGH A PUblic REgUlatory FrAMEWORK
}

\author{
ERIK S. KNUTSEN*
}

Automobile insurance in Canada is a product with a decidedly public purpose, a social contract. The provincial governments are heavily involved in the creation, regulation, drafting, and operation of the automobile insurance regime in any particular province. This public flavour to Canadian automobile insurance necessarily should affect the way one assesses the availability of insurance coverage in accident situations involving injuries or death. Understanding the limits of automobile insurance coverage for injuries or death in any given accident situation in Canada should be an exercise of interpretation akin to discerning the meaning of a public regulatory instrument with a public purpose, like a statute. This article proposes a novel interpretive framework for Canadian automobile insurance coverage disputes, one which accounts for the public purpose of such insurance and which searches for the true intent behind the language in the coveragegranting instruments. The framework also prompts an assessment of coverage decision consequences in a public compensatory regime and, in instances of coverage ambiguity, solves those ambiguities through basic tools of consumer protection.
Au Canada, l'assurance-automobile est un produit avec une raison d'être publique, notamment un contrat social. Les gouvernements provinciaux sont très mêlés à la création, la régulation, la rédaction et l'exploitation du régime d'assurance-automobile dans leurs provinces respectives. Cette dimension publique de l'assurance-automobile au pays doit forcément avoir une incidence sur la manière d'évaluer la garantie disponible dans des accidents avec blessés ou morts. La compréhension des limites de la garantie de l'assurance-automobile pour les accidents avec blessés ou morts au Canada devrait être un exercice d'interprétation qui ressemble à discerner la signification d'un instrument de réglementation publique avec une raison d'être publique, comme une statue. Cet article suggère un nouveau cadre d'interprétation pour les conflits sur les garanties de l'assurance-automobile au Canada, un cadre qui tiendrait compte du but public de cette assurance et qui viserait le véritable esprit des instruments accordant la garantie. Le cadre incite aussi l'évaluation des conséquences des décisions relatives à la garantie dans un régime compensatoire public et, dans les cas de garantie ambiguë, règle ces ambiguïtés au moyen de simples outils de protection du consommateur.

\section{TABLE OF CONTENTS}

I. INTRODUCTION . . . . . . . . . . . . . . . . . . . . 716

II. THE CANADIAN AUtOMOBILE INSURANCE

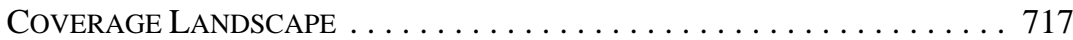

A. "GOVERNMENT-AS-INSURER" AND "MARKET CO-OPT"

MODELS OF INSURANCE DELIVERY $\ldots \ldots \ldots \ldots \ldots \ldots \ldots \ldots \ldots \ldots$

B. INPUT OF THE INSURANCE INDUSTRY $\ldots \ldots \ldots \ldots \ldots \ldots \ldots \ldots . \ldots \ldots$

C. Types of Available Automobile InSURANCE . . . . . . . . . . . 719

D. FORMS OF AUTOMOBILE INSURANCE

COVERAge InSTRUMENTS . . . . . . . . . . . . . . . . . . . . . 721

III. THE PRESENT INTERPRETIVE FRAMEWORK FOR

Determining Automobile Coverage SCOPE $\ldots \ldots \ldots \ldots \ldots \ldots . \ldots 723$

A. The Legislative Model $\ldots \ldots \ldots \ldots \ldots \ldots \ldots \ldots \ldots \ldots$

B. The Contractual Model $\ldots \ldots \ldots \ldots \ldots \ldots \ldots \ldots \ldots$

LL.M. (Harvard), Assistant Professor, Faculty of Law, Queen's University. The author would like to sincerely thank Craig Brown, Jeff Stempel, and two anonymous reviewers for ideas and insights, as well as Natalia Rodriguez, Law ' 10 and Jerri Phillips, Law '12 for their superb research assistance. 
C. INEFFECTIVE USE OF THE CONTRACTUAL MODEL

FOR AutOMOBILE INSURANCE COVERAgE DisPuTES . . . . . . . . 725

IV. Why The Present Interpretive Practice Does Not Work . . . . . . 735

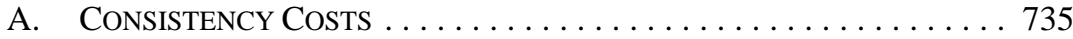

B. The INABILITY TO ACCOUNT FOR SOCIAL CONTEXT

AND SOCIAL IMPACT . . . . . . . . . . . . . . . . . . . . . 739

V. THE SOLUTION . . . . . . . . . . . . . . . . . . . . 740

A. The SPIRIT Of THE SOLUtion $\ldots \ldots \ldots \ldots \ldots \ldots \ldots \ldots \ldots \ldots 74$

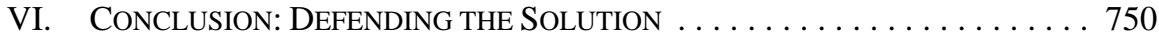

\section{INTRODUCTION}

Automobile insurance in Canada is a product with a decidedly public purpose, a social contract. ${ }^{1}$ The provincial governments are heavily involved in the creation, regulation, drafting, and operation of the automobile insurance regime in any particular province. ${ }^{2}$ This public flavour to Canadian automobile insurance necessarily should affect the way one assesses the availability of insurance coverage in accident situations involving injuries or death. Understanding the limits of automobile insurance coverage for injuries or death in any given accident situation in Canada is, and should be, an exercise of interpretation akin to discerning the meaning of a public regulatory instrument with a public purpose, like a statute. Yet what is driving automobile insurance coverage disputes in Canada? A great deal of confusion and unnecessary complexity.

This article proposes a novel interpretive framework for Canadian automobile insurance coverage disputes, one which accounts for the public purpose of such insurance and which searches for the true intent behind the language in the coverage-granting instruments. The framework also prompts an assessment of the consequences of coverage decisions to a public compensatory framework and, in instances of coverage ambiguity, solves those ambiguities through basic interpretive tools of consumer protection. Part II of the article details the public nature of Canada's provincial automobile insurance regimes and explains how automobile insurance coverage is offered to the driving public through various forms of coveragegranting instruments (statutory, regulatory, and contractual forms). Part III identifies the two models of interpretation currently utilized by courts in solving automobile insurance coverage disputes: the contractual model and the legislative model. It then proceeds to examine how a purely contractual model is inefficient and unpredictable in solving coverage disputes about the standard automobile insurance coverage clause and about overlapping insurance coverage issues. Part IV details how the present insurance contract interpretation framework is problematic because it is plagued by inconsistency costs and suffers an inability to account for the social context and social impact of coverage decisions. Part V

$1 \quad$ Regardless of the multitude of underlying reasons why automobile insurance in Canada is tinkered with by provincial governments, the overarching reason is to regulate in the "public interest": see e.g. Rose Anne Devlin, “Automobile Insurance in Ontario: Public Policy and Private Interests” (1993) 19 Can. Pub. Pol’y 298 at 299.

2 In Ontario, for example, extensive public inquiry and study has been involved in establishing its hybrid tort/no-fault automobile insurance system: see e.g. Final Report of the Ontario Task Force on Insurance (N.p.: Ministry of Financial Institutions, 1986); Government of Ontario, Report of Inquiry into Motor Vehicle Accident Compensation in Ontario (Toronto: Queen's Printer, 1988); Ontario Automobile Insurance Board, An Examination of Threshold No-Fault and Choice No-Fault Systems of Privately Delivered Automobile Insurance (Toronto: Queen’s Printer, 1989). 
presents a novel solution to replace the current Canadian insurance interpretation principles derived from contract law with a model that acknowledges the public regulatory context of Canadian automobile insurance as a system of public risk distribution. Part VI defends the solution and concludes.

\section{The Canadian Automobile InSURAnCE Coverage Landscape}

All Canadian motorists are required by law to have some form of provincially-approved automobile insurance. ${ }^{3}$ Provinces make automobile insurance mandatory for drivers so that there is a solvent and widespread system of compensation available in the event that the high-risk activity of driving leads to an injury. ${ }^{4}$ An injured accident victim can be assured that, for the majority of motor vehicle accident situations, there will be some mechanism of compensation because all drivers should be carrying an insurance product that will typically respond to injury-related losses in motor vehicle accidents. The automobile insurance system is designed, in effect, to maintain its compensatory framework by being funded by the users of the system - drivers. In a world without mandatory automobile insurance, a driver whose negligent driving causes an accident often may not have sufficient personal funds to adequately compensate the victim they injured. Without such compensation, the injured victim will often be forced to turn ${ }^{5}$ to the social safety net of welfare and other social benefits ${ }^{6}$ if they cannot recover adequate compensation from the party who harmed them. To ensure that provincial residents injured in automobile accidents have some form of compensation safety net in lieu of the public welfare system, provincial governments mandate, heavily regulate, and control the type and manner of automobile insurance coverage available to residents. ${ }^{7}$ Indeed, it is in the interest of the populace that the government ensure there is a system to provide some form of guaranteed compensation for most automobile accident injuries and deaths. Otherwise, the costs of such accidents are eventually borne by the public through social benefits.

Craig Brown, Insurance Law in Canada, looseleaf (Toronto: Thomson Carswell, 2002) vol 1. at 1-7 [Brown, Insurance Law]. See also Automobile Accident Insurance Benefits Regulations, Alta. Reg. 352/72; Statutory Conditions - Automobile Insurance, O. Reg. 777/93, both of which contain mandatory no-fault automobile insurance provisions.

$4 \quad$ See Craig Brown, "Private Insurance and Public Policy: Reconciling Conflicting Principles" (2009) 47 Can. Bus. L.J. 266 at 269 [Brown, "Private Insurance"]; Craig Brown, "Auto Insurance Reform in Ontario: A Long and Complicated Story” (1998) 3 Assurances 399.

5 Unless the accident victim has access to first party accident or disability insurance purchased either privately or offered by an employer. The majority of Canadians do not carry long-term disability insurance.

6 For example, provincial disability pensions and, if applicable to the situation, workers' compensation regimes.

$7 \quad$ See e.g. Insurance Act, R.S.O. 1990, c. I-8, s. 227(1) [Ontario, Insurance Act], which requires that insurers use only forms and policies approved by the Ontario Superintendent of Financial Services. Sections 227(2)-(5) stipulate that the Superintendent has the power to approve standard insurance forms for automobile insurance. 


\section{A. “GOVERNMENT-AS-INSURER” AND “MARKET CO-OPT” MODELS OF INSURANCE DELIVERY}

There are two basic ways that provinces exercise control over automobile insurance on behalf of the public. A minority of provinces operate compulsory automobile insurance for their residents entirely through a governmental agency, the "government-as-insurer" model. The agency is charged with managing the provincial automobile insurance scheme, including all aspects of insurance policy drafting, as well as managing and paying any insurance claims. The agency has a monopoly on the provision of automobile insurance products to the public. While consumers may choose to purchase their automobile insurance product through the public entity or, alternatively, through a private insurance company, the product is the standard provincially-drafted product and insurance claims are paid out through the public insurance agency, not the private insurer who may have sold the policy. There is no further choice for private-market alternatives. In essence, it makes no difference for insurance coverage purposes whether a consumer purchases the insurance at a government agency outlet or a private insurer. British Columbia, Manitoba, Quebec, and Saskatchewan all operate government controlled agencies that maintain the provincial automobile insurance system on behalf of the public.

The majority of provinces utilize a private "market co-opt” system ${ }^{8}$ whereby a government agency mandates, drafts, and controls the various types of insurance coverage available in the provincial market but private, for-profit insurance companies sell the insurance products and manage and pay the insurance claims. The market co-opt model has the government play a regulatory role while private insurers administer the government-mandated insurance products on a for-profit basis. Despite the fact that the government completely controls the format and content of available automobile insurance in the market co-opt model, ${ }^{9}$ private insurance companies are still able to profit from this heavily controlled market. Insurers enjoy a captive market and hold a monopoly on the limited insurance products available to the driving public, as automobile insurance is mandatory for all drivers. The law of large numbers ensures that an insurance company can still remain profitable though it offers a mandatory product, even to high-risk drivers. ${ }^{10}$ Not all drivers will have an accident at the same time, and insurers are able to increase insurance premium costs for high-risk drivers.

\section{B. INPUT OF THE INSURANCE INDUSTRY}

However, even though the provincial government approves and regulates the standard format of automobile insurance policies, the policies themselves are written with input from the private insurance industry, whether or not the province's automobile insurance regime utilizes private, for-profit insurers or a public government insurer. ${ }^{11}$ After all, a governmental

Craig Brown described the process whereby a government enlists the assistance of private insurers as “co-opt”: Brown, “Private Insurance,” supra note 4 at 266.

The automobile insurance coverage-granting instrument can be contained in a statute, regulation, or take the form of an insurance policy contract.

See Brown, "Private Insurance," supra note 4 at 273.

Courts in Canada habitually recognize insurance industry input in procuring language for provincial automobile insurance policies: see e.g. Thomas J. Donnelly, Insurance Law in Canada, looseleaf (Toronto: Thomson Carswell, 2002) vol. 2 at 17-15; Chilton v. Co-Operators General Insurance (1997), 32 O.R. (3d) 161 at 165, 168 (C.A.) (noting that automobile forms are drafted by the insurance industry); Somersall v. Friedman, 2002 SCC 59, [2002] 3 S.C.R. 109 at para. 47 [Somersall], where Iacobucci J., 
ministry drafting and approving insurance products likely cannot write automobile insurance coverage provisions from scratch and have the product be a rational and viable risk-based insurance product without some consultation and input from insurers with experience in the matter. Insurance industry groups, such as the Insurance Bureau of Canada and its provincial counterparts, provide input and advice to governments about the drafting, operation, and efficacy of automobile insurance products. This is especially so in provinces that utilize market co-opt models for automobile insurance provision. The Insurance Bureau of Canada, as industry representative, has an interest in maintaining a certain efficient national consistency with regard to automobile insurance in order to maintain the system's financial viability. It is thus no accident that all provincial automobile insurance coverage instruments are constructed in a very similar fashion, whether they exist in a statutory form or as a government-approved contractual insurance policy.

\section{Types of Available Automobile Insurance}

With the exception of Quebec and Manitoba's purely no-fault automobile insurance systems, the various other provincial automobile insurance schemes all offer a similar menu of insurance products. These other provinces vary the degree of emphasis on which particular insurance product is the primary source of compensation for motor vehicle accidents.

\section{1. $\quad$ First Party No-Fault ACCident Benefits}

First party no-fault accident benefits provide compensation to the insured accident victim under the accident victim's own insurance. Benefits may include some income replacement benefits, rehabilitation benefits, housekeeping benefits, and medical benefits. ${ }^{12}$ When an insured person is injured in a motor vehicle accident, that person's own insurance company pays the accident benefits to its own insured, the "first party.” The right to accident benefits is triggered by the occurrence of a motor vehicle accident in which the insured person is injured. Benefits are forthcoming without regard to the fault of the drivers involved in the accident. The injured victim does not have to prove that another driver's negligent behaviour caused the injuries. As long as an insured person is injured in an accident involving the "use or operation of an automobile,"13 the insured person will be entitled to benefits. All provinces offer some degree of first party no-fault accident benefits.

Quebec and Manitoba's automobile insurance systems are entirely no-fault systems that provide only for first party no-fault accident benefits to injured accident victims. ${ }^{14}$ Motor vehicle accident victims are not allowed to sue an at-fault driver in the tort system for

for the majority, states that "[t]he insurance industry was intimately involved in the development of the SEF 42 and subsequently the SEF 44” underinsured motorist insurance. Justice Binnie, dissenting, states that "[t]he language of motor vehicle insurance policies is generally regulated in each of the provinces. The insurance industry is consulted" (at para. 90).

12 See e.g. Statutory Accident Benefits Schedule - Accidents on or after November 1, 1996, O. Reg. 462/96, which details the government-approved benefits that are to be provided in the provincial no-fault insurance scheme.

13 For example, Ontario's statutory accident benefits are triggered by an "accident," which is “an incident in which use or operation of an automobile directly causes an impairment”: ibid., s. 2(1). In Alberta, insurance policies that provide medical and no-fault accident benefits are to be triggered by the "use or operation of an automobile”: see Insurance Act, R.S.A. 2000, c. I-3, ss. 641(1)(a), 642(1)(a) [Alberta, Insurance Act].

See generally Donnelly, supra note 11, c. 17. 
additional compensation based on that at-fault driver's tortious liability. They are only entitled to the first party no-fault accident benefits from their own insurance. There is no right to sue in tort for additional compensation in Quebec or Manitoba.

Ontario has a composite no-fault/tort automobile insurance regime where only certain severely injured accident victims have access to the tort system for additional compensation beyond their own first party no-fault accident benefits. ${ }^{15}$ All other motor vehicle accident victims in Ontario are entitled only to their first party no-fault accident benefits from their own insurance and are unable to resort to the tort system for additional compensation.

Saskatchewan operates a dual no-fault and tort auto insurance system where drivers can choose under which system to be insured. ${ }^{16}$ If an insured chooses the no-fault system, that insured receives a greater level of first party no-fault accident benefits under their own insurance policy, but their right to sue in tort for additional compensation is curtailed ${ }^{17}$ They cannot resort to the tort system to sue the at-fault driver for additional compensation.

All other provinces offer first party no-fault accident benefits to provide a minimum level of insurance compensation for insured accident victims, but utilize the fault-based tort system as the gatekeeper of motor vehicle accident compensation for injured accident victims. In order to be fully compensated, an injured accident victim must sue in tort the at-fault driver who caused the injuries. These other provinces therefore rely heavily on mandatory third party liability insurance to buttress the compensation needs of the injured.

\section{THIRD PARTY LIABILITY INSURANCE}

Third party liability insurance is triggered when the accident victim sues in tort the at-fault driver who caused the accident. Liability insurance is tort or behaviour insurance. Liability coverage is triggered when the insured person becomes legally liable to pay compensation to another because the insured's "use or operation of an automobile" somehow harmed the accident victim. ${ }^{18}$ The at-fault insured person's third party liability insurance pays the injured accident victim on behalf of the at-fault insured. ${ }^{19}$ Most Canadian provinces have a faultbased automobile insurance system where third party liability insurance is the primary target for the compensation of injured automobile accident victims. ${ }^{20}$

15 An accident victim in Ontario is restricted to first party no-fault accident benefits only, unless the victim's injury passes a verbal threshold of severity. To sue in the tort system, the victim's injury must be a permanent serious disfigurement, a permanent serious impairment of an important physical, mental, or psychological function, or the victim must have died: see Ontario, Insurance Act, supra note 7, s. 267.5; Court Proceedings for Automobile Accidents that Occur on or After November 1, 1996, O. Reg. 461/96.

16 Drivers have a choice to be insured under the provincial no-fault system, with access to first party accident benefits, or instead be insured to operate in the tort system and rely predominantly on third party liability insurance.

17 In Saskatchewan, an insured choosing the no-fault option cannot sue in tort for non-pecuniary damages (e.g. pain and suffering).

18 See e.g. Alberta, Insurance Act, supra note 13, s. 616(1)(a) (requiring that third party liability policies sold in the province respond to legal liability "arising from the ownership, use or operation of any such automobile”); Ontario, Insurance Act, supra note 7, s. 239(1)(a) (requiring that third party liability policies sold in the province respond to legal liability "arising from the ownership or directly or indirectly from the use or operation of any such automobile”).

19 The at-fault insured is also entitled to a litigation defence provided by the third party liability insurer.

20 British Columbia, Alberta, Nova Scotia, Newfoundland and Labrador, New Brunswick, and Prince Edward Island. 


\section{UNINSURED AND UNIDENTIFIED MOTORIST INSURANCE}

Uninsured and unidentified motorist insurance compensates the injured insured person using their own insurance, even though the accident may have been the fault of another driver. This is commonly called "hit-and-run" insurance. Uninsured and unidentified motorist insurance therefore compensates the first party insured for the damages for which the uninsured or unidentified driver would theoretically be liable as a result of the automobile accident, assuming they could have been found. An uninsured driver is a driver who has no applicable motor vehicle liability insurance that covers losses arising from "ownership, use or operation of an automobile.”"1 All provinces offer uninsured and unidentified motorist insurance as part of the standard mandatory automobile insurance package.

\section{UNDERINSURED MOTORIST INSURANCE}

Underinsured motorist insurance makes up the difference between the injured insured's own liability insurance limits and the limits of an inadequately insured at-fault driver whose driving behaviour injured the insured. Underinsured motorist insurance indemnifies the insured for the amount the insured is "legally entitled to recover from an inadequately insured motorist" for compensatory damages that arise from the "use or operation of an automobile.”22 So, to trigger coverage, the at-fault motorist must be legally liable to the victim for damages arising from the use or operation of an automobile and must also have insufficient insurance to cover the injured victim's full losses. The injured victim's own underinsured motorist insurance therefore makes up the difference between the inadequate insurance limits of the at-fault motorist and the injured victim's own underinsured motorist insurance limits. Underinsured motorist insurance is an optional, additional coverage available in provinces that have some fault-based tort component to their automobile insurance regime. Yet, even though it is optional, additional coverage, the provincial insurance authorities still approve and draft the language of the coverage.

\section{FORMS OF AUTOMOBILE INSURANCE COVERAGE INSTRUMENTS}

Provinces vary in the particular format of written instruments used to convey insurance coverage purchased by the driving public. Provinces utilizing either the government-asinsurer model or the market co-opt model may memorialize automobile insurance coverage provisions in either a legislative form, a form resembling a private insurance standard form contract, or some combination of both. In Ontario, for example, enabling language for basic coverage terms for third party liability insurance ${ }^{23}$ and uninsured motorist coverage ${ }^{24}$ are delineated in statutory sections under the provincial Insurance Act. Some coverage details of statutory no-fault accident benefits are contained in the statutory sections of the Insurance

See e.g. Ontario, Insurance Act, supra note 7, s. 265(1) (defining insurance coverage for "uninsured" and "unidentified" automobiles). See also Insurance (Vehicle) Act, R.S.B.C. 1996, c. 231, s. 20 [British Colombia, Insurance (Vehicle) Act].

22 See e.g. Government of Ontario, OPCF 44R: Family Protection Coverage, s. 3, online: Financial Services Commission of Ontario <http://www.fsco.gov.on.ca/english/forms/autoforms/endorsement/ default.asp> [OPCF 44R].

23 Ontario, Insurance Act, supra note 7, s. 239(1).

Ibid., s. 265(1). 
Act and are triggered by an accident involving "use or operation of an automobile." 25 Further operative details of the statutory no-fault accident benefits are also found in the Act's regulations, the Statutory Accident Benefits Schedule. ${ }^{26}$ The benefits are triggered by an "accident," 27 which is an "incident where the use or operation of an automobile" causes harm. In addition, Ontario provides automobile insurance consumers with an approved standard form insurance policy resembling an insurance contract. ${ }^{28}$ This "everyperson” form is the document that the insurance consumer gets. It sets out, in ordinary language, the coverage provisions for no-fault accident benefits, liability insurance, and uninsured motorist coverage. Finally, underinsured motorist insurance is sold to consumers in Ontario as an optional type of insurance coverage, for an additional cost. It is not provided for in the statutory language, but instead exists as an endorsement to the standard everyperson insurance policy. Yet even this endorsement is drafted and approved for sale by the governmental agency responsible for insurance. So, in short, for Ontario's market co-opt model of automobile insurance, the technical provisions of standard insurance coverage exist in statutory and regulatory form but consumers receive the more descriptive governmentapproved everyperson insurance policy format. Alberta's scheme uses a similar tactic — statutory provisions for the legalistic details, and an approved insurance policy form for the consumers that summarizes the basic details of the statutory provisions. In British Columbia, a province that utilizes the government-as-insurer model, statutory language describes the power of the provincial Insurance Corporation of British Columbia to set certain insurance coverages ${ }^{29}$ and that corporation then prints a consumer brochure that describes, in plain language, the various coverage benefits and restrictions in the provincial insurance scheme, called Autopac.

Regardless of the instruments chosen to convey automobile insurance products to the public, all provincial automobile insurance coverage is regulated and drafted by some arm of government. Because the legislative framework and approved insurance policy forms in each province must delineate what the provincial insurance plan covers and does not cover, largely the same standard wording is utilized no matter what instrument is employed and no matter what form the coverage takes (that is, no-fault or fault-based liability insurance). Insurance coverage is granted for accidents arising out of the "use or operation of an automobile.” Interestingly, nearly identical insurance coverage wording is also used in private-market automobile insurance policies available throughout the U.S. to American drivers. ${ }^{30}$ With a common phrase setting the limits of automobile insurance coverage, one would expect some level of consistency when courts are called upon to interpret the limits of that coverage. However, the remarkable level of provincial and national inconsistency and unpredictability in interpreting the identical coverage phrase prompts the singular question:

See e.g. ibid., s. 268(1.4), dealing with the indexation of benefits. Section 268(1) of the Act requires that all Ontario automobile insurance policies provide for no-fault statutory accident benefits. Statutory Accidents Benefits Schedule - Effective September 1, 2010, O. Reg. 34/10.

Ibid., s. 3(1), where "accident" is defined as "an incident in which the use or operation of an automobile directly causes an impairment or directly causes damage to any prescription eyewear, denture, hearing aid, prosthesis or other medical or dental device."

Government of Ontario, OAP 1: Ontario Automobile Policy Owner's Policy, online: Financial Services Commission of Ontario <http://www.fsco.gov.on.ca/english/forms/autoforms/endorsement/default. asp>. See British Columbia, Insurance (Vehicle) Act, supra note 21, s. 7.

See e.g. Jeffrey W. Stempel, Stempel on Insurance Contracts, 3d ed., looseleaf (New York: Aspen, 2006) vol. 2 at 22-80 [Stempel, Insurance Contracts]; Robert H. Jerry II \& Douglas R. Richmond, Understanding Insurance Law, 4th ed. (New Jersey: LexisNexis, 2007) at 974. 
why? This article will suggest that the answer likely lies in the application of principles of interpretation that are ill-suited to interpreting the public regulatory instruments that delineate automobile insurance coverage.

\section{THE PRESENT INTERPRETIVE FrAMEWORK FOR Determining Automobile Coverage Scope}

When an insured has a dispute with an insurer over the availability of automobile insurance coverage in a particular motor vehicle accident context, that insured must resort to the court system ${ }^{31}$ to resolve this coverage dispute. These disputes necessarily turn on the legal interpretation of the coverage-granting instrument. Since the insurance coverage is memorialized in writing in either a statute, regulation, or insurance policy document, the interpretation proceeds as a largely text-based exercise designed to discern the meaning of the coverage-granting language in the instrument. There are, at present, two basic models that courts employ to interpret coverage-granting instruments: a legislative model and a contractual model. What is most surprising is that there is, in practice, little consistency as to when either model is applied, regardless of the form of the coverage-granting instrument. There is also little internal consistency, even when a court indicates that it is applying one model over the other.

\section{A. The Legislative ModeL}

Most coverage-granting instruments exist as statutes or regulations passed by provincial legislatures. The instruments are drafted and controlled by governmental agencies. Courts can therefore deploy the standard tools of statutory construction when interpreting the limits of automobile insurance coverage as contained in statutes or regulations. These principles require that "the words of an Act are to be read in their entire context and in their grammatical and ordinary sense harmoniously with the scheme of the Act, the object of the Act, and the intention of Parliament."32 Despite the fact that all coverage-granting instruments are creatures of governmental action, very few court decisions involving coverage disputes follow a legislative interpretation model. ${ }^{33}$ In fact, even if courts mention that automobile insurance coverage is government-dictated, and even if courts specifically note that they are interpreting legislative language, they more often than not drift toward a contractual model of interpretation. ${ }^{34}$

\section{B. The Contractual Model}

Alternatively, and in most instances to date, a court can deploy standard common law interpretation principles derived specifically for divining meaning in adhesionary insurance

Or a provincial arbitration mechanism.

Marche v. Halifax Insurance, 2005 SCC 6, [2005] 1 S.C.R. 47 at para. 54, citing Elmer A. Driedger, Construction of Statutes, 2d ed. (Toronto: Butterworths, 1983) at 87.

One recent exception is found in Lewis v. Economical Insurance Group, 2010 ONCA 528, 322 D.L.R. (4th) 373 [Lewis], where Laskin J.A. used an exclusively legislative model to determine coverage in an instance where the insured walked into a steel pole protruding from a parked truck.

34 See e.g. Pilot Insurance v. Sutherland, 2007 ONCA 492, 86 O.R. (3d) 789 [Sutherland], where the Court applied a strictly contractual model to the interpretation of territorial limits of Ontario's underinsured motorist protection, despite there being some legislative components of the coverage-granting instruments. 
contracts. Recall that some automobile insurance products are put forth to consumers in a format that resembles a contract or standard insurance policy. These are the everyperson automobile insurance policy standard forms, written in ordinary language and summarizing the basic statutory coverages. They are also the additional optional underinsured motorist insurance products that can be tacked on to the mandatory insurance sold to consumers.

The principles in the contractual model are based on a bilateral contractual framework, similar to what exists in a private insurance market context. They are steeped in the notion that an insurance policy is typically a contract, a bargain between the insurance company and the insurance consumer. Theoretically, the insurance consumer in a non-automobile private market setting can typically choose not to purchase the insurance or, instead, may be able to opt for a different type of insurance policy package that may be available in the marketplace. At the same time, the contractual model attempts to balance this bargain concept (fiction though it is) with the notion that it is the insurer, not the insured, who has drafted the insurance contract and chosen the wording for coverage and exclusionary provisions. ${ }^{35}$ The insured has little choice but to accept or reject the insurance as it is worded because insurance policies are generally standard form contracts of adhesion. So, although the insured may have the choice to accept or reject the contract, the insured has little ability to alter the specific terms of the contract itself.

The Supreme Court of Canada has adopted contractual model interpretation principles to be applied when interpreting insurance policy language. ${ }^{36}$ The interpretive exercise is to proceed in two stages, both based on the text of the coverage-granting instrument: the "intention" stage and the "ambiguity" stage. ${ }^{37}$ The intention stage attempts to discern the intention of the parties in the bargain - the insurer and the insured. A court is to use the plain meaning of the insurance policy, read as a whole, and determine what commercially sensible result the parties intended. If, however, in attempting to uncover the intention of the parties, a court is faced with contractual language that yields an ambiguous interpretation of some wording, a court is to proceed to stage two of the interpretive exercise, the ambiguity stage. An ambiguous result is one where there are at least two commercially reasonable interpretations of the clause at issue. At the ambiguity stage, principles of equity and balance come into play to solve the ambiguity. Basically, any ties in equally plausible interpretive results are decided in favour of the insured, who did not draft the contract. As part of this stage, and in recognition of the imbalance of drafting power between insured and insurer, courts are to interpret clauses granting coverage in a broad fashion, and clauses excluding coverage in a narrow fashion. A court may apply the contra proferentem doctrine to construe the language at issue against the interests of the drafter, the insurer. A court may also give

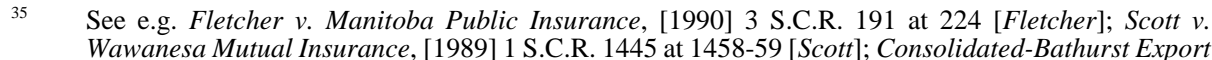
Ltd. v. Mutual Boiler and Machinery Insurance (1979), [1980] 1 S.C.R. 888 at 899 [ConsolidatedBathurst].

36 See e.g. Brissette Estate v. Westbury Life Insurance, [1992] 3 S.C.R. 87; Reid Crowther \& Partners Ltd. v. Simcoe \& Erie General Insurance, [1993] 1 S.C.R. 252 [Reid Crowther]; Consolidated-Bathurst, ibid.; Jesuit Fathers of Upper Canada v. Guardian Insurance Co. of Canada, 2006 SCC 21, [2006] 1 S.C.R. 744 [Jesuit Fathers]; Non-Marine Underwriters v. Scalera, 2000 SCC 24, [2000] 1 S.C.R. 551; Scott, ibid.; Derksen v. 539938 Ontario Ltd., 2001 SCC 72, [2001] 3 S.C.R. 398 [Derksen]; Cooperators Life Insurance v. Gibbens, 2009 SCC 59, [2009] 3 S.C.R. 605; Progressive Homes Ltd. v. Lombard General Insurance Co. of Canada, 2010 SCC 33, [2010] 2 S.C.R. 245.

37 See e.g. Barbara Billingsley, General Principles of Canadian Insurance Law (Markham, Ont.: LexisNexis, 2008) at 137-39; Brown, Insurance Law, supra note 3 at 8.2. 
effect to the reasonable expectations of the parties in order to produce a commercially sensible result. Despite the fact that courts often recite verbatim the contractual model principles from case to case, surprisingly inconsistent results nonetheless arise from the application of these principles.

\section{INEFFECTIVE USE OF THE CONTRACTUAL MODEL FOR AUTOMOBILE INSURANCE COVERAGE DISPUTES}

Examining how past and current Canadian courts struggle with the contractual model of interpretation in common automobile insurance coverage disputes demonstrates that using a contractual model for interpreting coverage-granting instruments leads to unpredictable inconsistencies in interpretive result. It also breeds artificial judge-made distinctions and prompts courts to adhere to a functionally limited text-based methodology that is inappropriate for a public automobile insurance system designed with public values in mind. Two particular examples demonstrate how problematic the contractual model alone is for coverage disputes. First, there is a convoluted line of common coverage disputes that attempt to define the limits of the standard automobile insurance coverage clause: coverage for injuries or death arising from the "use or operation of an automobile." Second, courts have created serious insurance market gaps and inconsistencies when determining coverage disputes involving overlapping automobile and non-automobile insurance policies. Tracing the development of both of these examples in the jurisprudence demonstrates how a purely contractual interpretive framework is insufficient for producing predictable results for disputants.

\section{The “Use AND Operation” COVERAGE CASES}

Cases that interpret the coverage phrase "use or operation of an automobile" provide the most troubling example of the contractual model's inability to predictably solve coverage disputes in a public automobile insurance regime. Specifically, they illustrate the inconsistencies that have arisen from applying interpretive models to solve automobile insurance coverage disputes. Tracing the line of jurisprudence from the Supreme Court of Canada's 1995 decision in Amos v. Insurance Corp. of British Columbia ${ }^{38}$ to its 2007 decisions in Citadel General Assurance v. Vytlingam ${ }^{39}$ and Lumbermens Mutual Casualty Co. v. Herbison ${ }^{40}$ and beyond provides demonstrable evidence of a problematic interpretive framework.

\section{a. Broad Coverage Under Amos}

The Supreme Court of Canada created an extra-contractual interpretation solution for automobile insurance coverage in Amos. The dispute centred around whether or not Mr. Amos could receive British Columbia's first party no-fault insurance benefits as compensation for being shot by a gang while he was driving his van in California. His insurance coverage would be triggered if he could prove that his injuries were "caused by an 
accident that arises out of the ownership, use or operation of a vehicle." ${ }^{41}$ The members of the gang tried to gain entry into the van while the van was slowly moving. They smashed the driver's side window of the van. One member of the gang was clearing the broken glass away from the window with a gun when the gun discharged, seriously injuring Amos.

To determine the scope of insurance coverage, Major J. combined a limited legislative interpretive model, some tenets of a contractual model, and an additional extra-contractual doctrinal test. He noted the legislative intent of first party no-fault accident benefits and discussed the legislative evolution of the coverage, consistent with the application of a legislative model. However, he then attempted to summarize two prior jurisprudential methods for determining coverage under the standard clause: the "purpose" test ${ }^{42}$ and the "causation" test. ${ }^{43}$ After summarizing these separate approaches, Major J. then applied them both to the factual scenario in Amos to solve the coverage dispute. This promulgated a new, extra-contractual doctrinal set of tests. The newly constructed Amos test required insureds seeking coverage to prove (1) that the accident resulted from the ordinary and well-known activities to which automobiles are put (the purpose test); and (2) that there is some causal relationship, beyond merely incidental or "but-for," between the injuries and the ownership, use, or operation of the automobile (the causation test). The causation test is met so long as there is no intervening act, independent of the use of the automobile, that breaks the chain of causation leading from use to the injury. ${ }^{44}$ One does not need to prove a direct or proximate causal relationship. As long as the "use or operation of a motor vehicle in some manner contributes to or adds to the injury," 45 automobile insurance coverage is triggered.

Justice Major held that the shooting was not random, ${ }^{46}$ but rather the direct result of the gang member's frustrated attempt to enter Amos' van. Therefore, the shooting arose out of Amos' use and operation of his van. The Court held that the policy granted coverage as no other acts, independent of automobile use, interrupted the chain of causation between the use of the vehicle and the harm. The vehicle use contributed to the injury that occurred.

Following Amos, courts adhered to the Amos purpose and causation tests when interpreting the coverage grant "use or operation of an automobile." The use of either a legislative or contractual model of interpretation ceased. The two-part Amos test attempted to resolve a wide range of coverage disputes over a variety of types of insurance coverage contained in varying kinds of coverage instruments. Courts often produced conflicting results using the rather broad and coverage-friendly Amos two-part test. ${ }^{47}$ Whether the coveragegranting instrument was a statute, regulation, contract, or a combination of these, the Amos test did not differentiate in approach. Some of the conflicting case results include injury or death from:

Revised Regulation (1984) under the Insurance (Motor Vehicle) Act, B.C. Reg. 447/83, s. 79(1), cited in Amos, supra note 38 at para. 9.

42 The purpose test first arose in Stevenson v. Reliance Petroleum Ltd., [1956] S.C.R. 936 at 941.

43 The causation test first arose in Law, Union \& Rock Insurance Company Limited v. Moore's Taxi Limited (1959), [1960] S.C.R. 80 at 84-85 [Law, Union \& Rock].

Amos, supra note 38 at para. 27.

Ibid. at para. 26.

Indeed, Major J. held that a truly random shooting would not be covered as such an event would not be related to the use or operation of the vehicle: ibid. at para. 28.

$47 \quad$ See David M. Shoemaker, “'Arising Out of the Ownership, Use or Operation’: Tracing the Development and Questioning the Trend of Canadian Automobile Insurance Coverage” (1997) 76 Can. Bar Rev. 428. 
(1) projectiles, including shooting injuries; ${ }^{48}$

(2) dog bites; ${ }^{49}$

(3) suicides and murder-suicides in vehicles; ${ }^{50}$

(4) assaults around vehicles; ${ }^{.1}$

(5) using a vehicle to drop people off; ${ }^{52}$

(6) falling in a parking lot at a funeral home; ${ }^{53}$

(7) diving after being driven to a beach; ${ }^{54}$

(8) suffering extreme frostbite after falling into a river because an inoperative vehicle left the driver stranded; ${ }^{55}$

(9) pouring cement from a truck; ${ }^{56}$ and

See Chan v. Insurance Corp. of British Columbia, [1996] 4 W.W.R. 734 (B.C.C.A.) [Chan] (coverage for a front-seat passenger for injuries suffered when struck by a brick thrown from an oncoming vehicle); Axa Insurance v. Dominion of Canada General Insurance (2004), 73 O.R. (3d) 391 (C.A.) [Axa] (coverage when claimant struck in the eye with a bungee cord while tying friend's boat to a trailer). But see Chisholm v. Liberty Mutual Group (2002), 60 O.R. (3d) 776 (C.A.) [Chisholm] (no coverage when insured injured by gunshots from unknown assailants who shot into his vehicle). Taylor v. Maris, 2004 BCCA 391, 30 B.C.L.R. (4th) 284 (dog bites woman while dog in box of truck). ING Insurance Co. of Canada v. Harder Estate, 2008 ABCA 201, 432 A.R. 231 [Harder] (no third party liability coverage for father/son murder-suicide with shotgun while in parked vehicle); Holdbrook $v$. Emeneau, 2000 NSCA 48, 204 N.S.R. (2d) 96 (no third party liability coverage for man sitting in parked truck who tried to light himself on fire). But see Vijeyekumar v. State Farm Mutual Automobile Insurance (1999), 44 O.R. (3d) 545 (C.A.) (insured granted accident benefit death benefits from suicide by carbon monoxide poisoning from stationary vehicle).

51 Jenkins (Litigation guardian of) v. Zurich Insurance Canada (1997), 193 N.B.R. (2d) 135 (C.A.) [Jenkins] (no coverage for boy pulled off stairs of school bus and beaten by other students); Tench $v$. Erskine, 2006 NSSC 115, 244 N.S.R. (2d) 55 [Tench] (no coverage when passenger assaulted driver who rear-ended vehicle stopped at traffic light); Duval v. Alberta Motor Assn. Insurance, 2000 ABQB 87, 259 A.R. 195 [Duval] (no coverage when insured got out of vehicle to assault other driver as causation test was not satisfied). But see Saharkhiz v. Underwriters, Members of Lloyd's, London, England (2000), 49 O.R. (3d) 255 (C.A.) [Saharkhiz] (accident benefits coverage for taxi driver who was assaulted by passengers who refused to pay fare); Beger v. MacAstocker Estate (Public Trustee of) (1996), 192 A.R. 241 (Q.B.) [Beger] (coverage when driver assaulted after intentional collision); Itani v. Stan Poulsen Trucking Ltd. (2002), 2003 ABCA 8, 320 A.R. 375 [Itani] (coverage when insured, who was stopped at a red light, was assaulted when another driver walked over; use of vehicle created anger resulting in assault). Stempel notes that, in cases involving abduction or sexual assault and vehicles, the vehicle is more than the mere situs of the assault - it is the modus operandi that makes the assault even possible, and also that assists in escape: Stempel, Insurance Contracts, supra note 30 at 22-81. Lefor (Litigation guardian of) v. McClure (2000), 49 O.R. (3d) 557 (C.A.) [Lefor] (coverage when young child runs out onto road as mother leaves vehicle and attempts to cross road while holding childrens' hands). See also Wu (Guardian ad litem of) v. Malamas (1985), 21 D.L.R. (4th) 468, (B.C.C.A.) [Wu]. But see Kopas v. Western Assurance (2008), 92 O.R. (3d) 688 (Sup. Ct. J.) [Kopas] (five-year-old child got out of car in parking lot and another car backed over him; no coverage as boy had got to fence before accident and was out of vehicle). Hachey-Tweedle v. Trillium Funeral Service, [1999] O.J. No. 883 (Ct. J. (Gen. Div.)) (QL) (fall in a funeral home parking lot satisfied purpose and causation tests). coverage when drunken person driven to beach and 25 minutes later dives into the water and is seriously injured). Greenhalgh v. ING Halifax Insurance (2004), 72 O.R. (3d) 338 (C.A.) (no coverage as chain of causation severed). worker knocked into excavation hole by moving conveyor on parked cement truck). 
(10) illnesses during a vehicle trip. ${ }^{57}$

\section{b. Amos Test Restricted under Vytlingam and Herbison}

Likely in response to the inconsistencies in case results after Amos, the Supreme Court of Canada again attempted to clarify the procedure for automobile coverage interpretation in Vytlingam and Herbison. The Court ratcheted down the broad Amos test in these two simultaneously released cases, which dealt with underinsured motorist coverage and third party liability coverage for "use or operation" of an automobile, respectively (recall that Amos decided coverage for first party accident benefits). The Court in both of these cases utilized the Amos two-part test, plus an extra-contractual model to resolve the interpretive coverage question at issue.

Vytlingam involved determining coverage under Ontario's standard underinsured motorist insurance. Unlike the first party no-fault statutory insurance benefits at issue in Amos, the Court framed its analysis around the fact that this type of insurance is triggered by the actions of a third party tortfeasor.

While travelling in North Carolina, the plaintiff and his passengers were seriously injured when the plaintiff's vehicle was struck by a large boulder, which had been dropped from an overpass by two men intoxicated by drugs and alcohol. The men had been using their vehicle to haul the 30-pound boulders to the edge of the overpass, and planned to use the vehicle as their getaway car after their mischief. The plaintiff sued his own insurer for coverage under his policy's underinsured motorist endorsement. ${ }^{58}$ That endorsement is designed to make up the difference between the shortfall of the at-fault tortfeasor's available insurance (here $\$ 25,000$ ) and the insurance coverage limits carried by the victim's own third party liability insurance. ${ }^{59}$ It is triggered when the injured accident victim is legally entitled to recover, from an "inadequately insured motorist," some compensation for injuries arising from the "use or operation of an automobile." An "inadequately insured motorist," under the endorsement, means the owner or driver of an automobile "for which the total motor vehicle liability insurance ... is less than the limit" of the insured's coverage. ${ }^{60}$

While Binnie J. mentions principles that are standard in applying a contractual model of interpretation, ${ }^{61}$ and notes that differing statutory provisions govern no-fault insurance and liability insurance, ${ }^{62}$ the operative interpretive tools he adopts are from neither a contractual nor a legislative model of interpretation. As Major J. did in Amos, Binnie J. created an extra-

Marjak Services Ltd. v. Insurance Corp. of British Columbia, 2004 BCCA 455, 244 D.L.R. (4th) 700 (purpose and causation tests met when passenger in a vehicle became seriously ill during the course of a long driving trip).

58 See OPCF 44R, supra note 22.

59 Ibid., s. 3. The underinsured motorist coverage is triggered as follows [emphasis added]:

[T] he insurer shall indemnify an eligible claimant for the amount that he or she is legally entitled to recover from an inadequately insured motorist as compensatory damages in respect of bodily injury to or death of an insured person arising directly or indirectly from the use or operation of an automobile.

Ibid., s. 1.5(a).

$61 \quad$ Vytlingam, supra note 39 at para. 4. However, citing Reid Crowther, supra note 36 at 269, Binnie J. notes that consideration must be given to the reasonable expectations of insured and insurer.

62 Justice Binnie calls the underinsured motorist coverage “indemnity” insurance: Vytlingam, ibid. at para. 16. 
contractual interpretive solution. He drew distinctions in the endorsement's terminology that do not exist in either the wording of the endorsement or any statutory provisions governing automobile insurance. He may, in fact, have indirectly been applying a purposive approach to automobile insurance coverage, a technique common in the legislative model of interpretation. However, the approach seems to focus on what Binnie J. believes are the commercially sensible distinctions to be drawn between no-fault and liability insurance, and nowhere in the judgment does Binnie J. refer to the endorsement as anything but a private contract between insurer and insured. ${ }^{63}$ So an alternate explanation for his interpretation methodology could be that Binnie J. applied the first stage of the contractual approach (the "intention" stage) and the analysis stopped there. To glean the "intention" of the insured and insurer, Binnie J. drew distinctions between no-fault accident benefits and liability insurance compensation, as well as distinctions between the actions of the at-fault party versus the actions of the insured.

In the end, Binnie J. held that coverage provided under the underinsured motorist endorsement was only triggered if the at-fault motorist who harmed the accident victim committed the tort "as a motorist," with an unbroken chain of causation linking the tortfeasor's conduct as a motorist to the harm suffered by the victim. He determined that Amos was not a "template" to solve the coverage issue in Vytlingam because the types of insurance were different. ${ }^{64}$ Because the Amos situation did not deal with "indemnity" insurance, ${ }^{65}$ it did not require the presence of an at-fault motorist, but focused instead on the use of the insured's vehicle. Justice Binnie held that the Amos test should not be as restrictive as the test for solving coverage disputes involving indemnity insurance because insured drivers expect no-fault benefits to be available when an accident occurs while they are making "ordinary and well-known" use of vehicles: "This is the mutual expectation of both the insured and the insurer." 66 The coverage in Vytlingam, by contrast, is triggered by the tort of another party and thus requires the court to analyze the facts surrounding that vehicle being used "as a motor vehicle" (the purpose test) and the motorist committing the tort "as a motorist" (a new requirement in the causation test).

While not much "will be excluded as aberrant to the use of a motor vehicle as a motor vehicle," ${ }^{\prime 67}$ Binnie J. constricted the once broad Amos causation test by requiring that, for non-first party accident benefit insurance situations (like underinsured motorist coverage), there must be an unbroken chain of causation from the negligence of a motorist as a motorist to the negligence that allegedly caused the harm. Just because an automobile is in the factual matrix no longer means that coverage is presumptively granted. The "motoring” activity must

Indeed, he notes that no-fault and liability insurance are "to be interpreted in the context of a motor vehicle policy,” evidence of a contractual view of automobile insurance: ibid.

Ibid. at para. 9.

By “indemnity,” Binnie J. refers to liability or “tort” insurance, where the trigger is the behaviour of a tortfeasor, as opposed to first party accident insurance benefits, which are triggered by injury of the insured, regardless of the tortfeasor's actions. It is interesting to note that this is a relatively uncommon use of the term "indemnity" in insurance law. All insurance that "indemnifies" or pays the insured who purchased the policy can often be referred to as "indemnity" insurance: Brown, Insurance Law, supra note 3 at 1.2(c). In Vytlingham, ibid., the underinsured motorist endorsement was purchased by the insured accident victim to indemnify him in the event someone harmed him and had inadequate insurance coverage. Thus, Binnie J.'s use of the term "indemnity" as a distinguishing characteristic of underinsured motorist insurance is, perhaps, misplaced.

Vytlingam, ibid. at para. 13.

Ibid. at para. 22. 
cause the loss in an uninterrupted fashion. It is no longer sufficient, as in Amos, that the vehicle "in some manner contributes to or adds to the injury."68

As in Amos, if the vehicle's involvement is somehow severable from the use or operation of the vehicle, no coverage is provided. In Vytlingam, Binnie J. held that the rock throwing was a severable tort from the use or operation of the vehicle. ${ }^{69}$ The tort that harmed the plaintiff was not motorist negligence - it was rock throwing. The use or operation of the motor vehicle had ended by the time the rock was dropped. The fact that the vehicle was used to transport the heavy rocks or as a getaway vehicle was not enough in the liability insurance context to give the vehicle a sufficient causal role to trigger coverage. ${ }^{70}$ As a result, no coverage was granted under the policy. Justice Binnie tightened the two-part Amos test using an extra-contractual restriction on the operative language in the underinsured motorist endorsement by requiring that the harm be committed by the at-fault motorist while acting as a "motorist," as that was the imputed intention of the parties to the endorsement.

Herbison, the companion case to Vytlingam, applied the same restricted Amos test from Vytlingam to a standard third party liability insurance situation. A hunter, Mr. Wolfe, stepped away from his pickup truck in the early morning darkness, left his engine running, and fired his rifle at a target in his headlights, thinking that he saw a deer. The target turned out to be Mr. Herbison, Wolfe's nephew. Herbison was seriously injured from the gunshot and sought to recover from Wolfe in tort. The case considered whether or not Wolfe's third party automobile liability insurance policy would cover Wolfe for his negligent conduct and ensuing liability to Herbison.

Wolfe's standard Ontario motor vehicle liability policy provided “coverage for loss or damage 'arising from the ownership or directly or indirectly from the use or operation' of an automobile owned by the insured." ${ }^{71}$ As in Vytlingam, the Court focused its analysis on the tortfeasor's vehicle. The Court held that Wolfe met the purpose test from Amos as he was using his vehicle as a motor vehicle; it was his transportation for hunting. However, because Wolfe interrupted his motoring to begin hunting, he broke the chain of causation from vehicle use to injury. Even though Wolfe was using the vehicle as transportation to hunt, had just left the vehicle moments before, still had the engine running, and used the headlights to illuminate his unlucky target, that was not enough to satisfy the more narrow causation test

Ibid. at para. 24

69 This was not the finding at trial, where the Court held that the insurance policy covered the injuries resulting from the rock throwing: Vytlingam (Litigation guardian of) v. Farmer (2004), 23 C.C.L.I. (4th) 267 (Ont. Sup. Ct. J.). The Court of Appeal applied the broader Amos test and did not restrict the causation step of the test to catch only torts committed by the rock thrower "as a motorist." The fact that the rocks could not be carried without the motor vehicle, and the fact that the vehicle was to be used as a getaway car were determinative in the Court of Appeal's conclusion that the causation test was satisfied. Justice Juriansz dissented and restricted the causation analysis in the same manner as Binnie $\mathrm{J}$.: the motorist must commit the tort as a motorist: Vytlingam (Litigation guardian of) v. Farmer (2005), 76 O.R. (3d) 1 (C.A.).

70 As discussed below, the vehicle use would have satisfied the original incarnation of the Amos causation test, as vehicle use did, in some manner, contribute to the injury and thus there would have been coverage.

$71 \quad$ Herbison, supra note 40 at para. 4. 
for liability insurance, as set out in Vytlingam. ${ }^{72}$ Herbison was not injured by negligent vehicle use; he was hurt by a gunshot. The Court held that an intervening act may not always break the chain of causation as long as the act is not an "abnormal incident of the risk" created by the use of the vehicle. ${ }^{73}$ That was not the case here. This accident would not arise in the "ordinary course" of using a vehicle, according to the Court. The negligent act of shooting was severable from Wolfe's actions as a motorist. ${ }^{74}$

Under the original incarnation of the Amos test, the Court likely would have found coverage for the accident victims in both Vytlingam and Herbison. The Amos test for first party no-fault accident benefits does not require an unbroken chain of causation, but instead requires only that the use of the tortfeasor's vehicle somehow contributed to the injury. Thus the analysis would not have turned on whether or not the tort that caused the harm was committed by the thrower ${ }^{75}$ or shooter ${ }^{76}$ as a motorist at the precise moment of the tort. There was likely enough of a relationship to vehicle use in both scenarios to justify auto coverage under the former Amos test. This explains the pro-coverage results at the Court of Appeal in both Vytlingam and Herbison. The broader Amos test, however, has now been relegated solely to first party no-fault accident benefit situations (and yet only sometimes, by some courts).

\section{c. $\quad$ Further Unpredictability Post-Vytlingam and Herbison}

The application of the narrowed causation test from Vytlingam and Herbison has restricted access to insurance coverage involving the interpretation of the "use or operation of an automobile" clause in cases where injury was caused by a third party tortfeasor. The behaviour of the at-fault motorist, as a motorist, must cause harm in an unbroken chain of causation. Courts have thus denied coverage for a drive-away shooting in a restaurant, ${ }^{77}$ a father/son murder-suicide, ${ }^{78}$ a couple shot by robbers while parked in the driveway of their own home, ${ }^{79}$ and an assault following a police pursuit. ${ }^{80}$ However, some courts are still not

The majority of the Ontario Court of Appeal held that Wolfe's use of his truck was sufficient to meet the causation test. In addition, he suffered from some disability that made using a truck a necessity during his hunting, as walking was difficult: Herbison v. Lumbermens Mutual Casualty Co. (2005), 76 O.R. (3d) 81 (C.A.).

73 Herbison, supra note 40 at para. 13, citing Derksen, supra note 36 at para. 33. The example given by Binnie J. is Lefor, supra note 52, where a mother parked her vehicle on the opposite side of the street, left it running, then ran across the street with the child to drop her off at another home. The child was hit by a car as she ran across the street. The Ontario Court of Appeal held that the mother's negligence in parking and crossing the street did not break the chain of causation from vehicle use to injury. The negligent parking was so closely intertwined with the mother's post-vehicle conduct that the acts were not severable.

$74 \quad$ Herbison, ibid. at para. 11.

75 The fact that the vehicle in Vytlingam had some causal role in transporting the heavy rocks to the overpass and serving as a getaway car for the throwers themselves would likely have been enough to fulfill the causation test previously used under Amos.

76 The fact that the Herbison vehicle and its headlights were used during Wolfe's hunt, mere moments before he fired his rifle, would likely also have been enough to fulfill the causation test previously used under Amos.

77 Russo v. John Doe (2008), 63 C.C.L.I. (4th) 113 (Ont. Sup. Ct. J.) [Russo] (no coverage under underinsured or uninsured motorist insurance as shooting was a separate incident from the use of an automobile).

78 Harder, supra note 50 (father shot himself and son while sitting in truck; no third party liability coverage as liability arose from shooting, not the use of the motor vehicle).

79 Zukowski v. O’Bee, 2010 ABQB 421, 28 Alta. L.R. (5th) 350 [Zukowski] (no access to motor vehicle accident claims fund for victims because accident not arising out of use or operation of a motor vehicle). Letkeman v. Ouellette, 2009 ABQB 484, 484 A.R. 13 [Letkeman] (injuries following resisted attempt to remove driver from vehicle preceded the distinct break in the causal chain that the assault constituted). 
completely clear on the reach of the test, as uninsured motorist coverage has been granted for a woman injured in a drive-away purse-snatching. ${ }^{81}$ Similar cases applying the prior incarnation of the Amos test may have found coverage. ${ }^{82}$

In instances where first party no-fault accident coverage is at issue, some courts assert that the broader Amos two-part test applies, with the more expansive, coverage-friendly causation step $^{83}$ and these courts distinguish their facts from the more restrictive Vytlingam/Herbison approach. However, some courts resolving coverage disputes over no-fault accident benefits have also applied the restrictive Vytlingam/Herbison approach. ${ }^{84}$

The "use or operation” coverage cases reveal a disturbing jurisprudential trend. Even though all forms of automobile insurance are strictly products of provincial governments, and akin to public regulatory documents, the coverage-granting instruments have been relegated by courts to something less than a statute, and even less than a contract. The interpretive analyses from Amos, Vytlingam, and Herbison created an extra-contractual interpretive regime based on distinctions that are not supported by reference to any interpretive tools from a legislative model. No court has examined the public purpose of the particular coverage provisions at issue, nor was the legislative history or intent explored. Additionally, only rarely were the interpretive analyses incorporating standard principles from a contractual model used, and the appropriateness of that for public automobile insurance in a public context is certainly questionable.

Instead, the analysis for the "use or operation" coverage clause incorporates a causal narrative as a coverage limiter: the vehicle must cause the harm in some varying degree. First, courts must trace the use of the vehicle and its causal role in the harm. This can get extremely confusing and unpredictable, as will be discussed below. Second, the analysis relaxes the causation requirement for first party no-fault accident benefits and tightens the requirement for all other types of automobile insurance, based on what are perhaps artificial intentions that are not truly supported by a thorough legislative analysis. Third, the use of the at-fault motorist's vehicle as a vehicle has become determinative in all contexts except first party accident benefits. Under a contractual model, this would be akin to adding words to a contract of adhesion that hurt, rather than help, the insured's interests. As an interpretive process, then, the logic is incongruous.

Hannah v. John Doe, 2010 BCCA 141, 318 D.L.R. (4th) 699 [Hannah] (unidentified passenger in van snatched woman's purse and accelerated; woman thrown and dragged until purse ripped; driver's acceleration caused harm here and was use or operation of motor vehicle as a motor vehicle).

82 See Part III.C.1.b, above.

83 See e.g. Constantin v. Manitoba Public Insurance, 2008 MBCA 5, 57 C.C.L.I. (4th) 200 (insured was carrying propane stove in front seat of vehicle while driving with lit cigarette, turned around to reposition the stove, and the stove exploded); Haekel v. Allstate Insurance Co. of Canada, 2007 ABCA 419, 422 A.R. 131 (insured fatally stabbed after vehicle accident; Amos test applies but coverage clause required injury to be caused by use or operation of an automobile "directly and independent of all other causes”). Indeed, Stempel notes that first party no-fault coverage may beg for a broader interpretation, as accident victims likely had to give up rights to sue in tort in exchange for first party benefits under the no-fault system: see Stempel, Insurance Contracts, supra note 30 at 22-82. However, in Canada most provinces utilize somewhat of a hybrid system where the greatest proportion of compensation still exists in the tort context. It is therefore questionable why the no-fault benefits are to be read broadly and the liability coverage in tort not so, when both coexist in the same public provincial system.

84 See e.g. Hagen v. Hillcrest Enterprises Ltd., 2008 SKQB 142, [2008] 7 W.W.R. 534 (insured burned when truck caught fire in wheat field and insured attempted to extinguish fire; first party accident benefits coverage allowed even though stricter Vytlingam/Herbison test applied). 
However, the end results stemming from the Vytlingam/Herbison cases may intuitively seem to make sense: automobile insurance coverage is restricted only to incidents where a motor vehicle being used as a motor vehicle had a direct causal role in bringing about the harm. Otherwise, the harm is not properly the subject of "automobile" insurance. The postAmos cases may have simply caught too much in the web of "use or operation." Coverage was too generous and a proper balance between the interests of the insured and the insurer needed to be restored through a more tightened test for coverage.

All that may be true. But an interpretive analysis that leads to a predictable and consistent result and that effectively balances the public interests in the automobile insurance system should really be the goal. The reductionist, extra-contractual, causation-based analysis for coverage does not do this. It simply breeds more litigation, as causation is often in the eye of the beholder. Mixing parts of a legislative model with a contractual model of interpretation without any consistent principle leads to further confusion for litigants and courts alike. Drawing determinative distinctions between the types of insurance coverage that are available in a publicly regulated automobile insurance system adds little to the end goal as well. Most important, the analysis fails to account for the true public consequences of the coverage decisions. This important factor becomes all too clear if one examines how courts interpret language in other automobile insurance coverage contexts.

\section{The Overlapping Coverage Problem}

The second problematic area of automobile insurance coverage involves how court decisions about coverage disputes have the potential to impact the entire insurance compensation network by failing to consider the effect of automobile insurance decisions on non-auto insurance contexts. In Derksen ${ }^{85}$ the Supreme Court had to decide a coverage contest between an automobile liability insurance policy and a commercial liability policy in an accident situation that involved the serious injury and death of children on a schoolbus. The insured at-fault driver failed to properly clean up a work site and a heavy sign base therefore catapulted through the window of an oncoming schoolbus, thus implicating elements of both driving negligence and negligent work site cleanup. The coverage clause for the standard Ontario automobile policy was the "use or operation of an automobile" coverage clause. The commercial liability policy covered all actions for which the insured may be legally liable, but had an exclusion for losses arising from the "use or operation of an automobile." The coverage clause of the automobile liability policy was thus also the exclusion for the commercial liability policy ${ }^{86}$ The Court held that losses could be concurrently caused by more than one cause, and both insurance policies could cover the loss.

The Court approached the interpretive question as a purely contractual one,${ }^{87}$ despite the fact that there are two serious and probing ramifications to relying strictly on a contractual model of interpretation in this particular case. While the commercial liability policy was a

$85 \quad$ Supra note 36.

86 As is common for various lines of insurance. Tom Baker calls these parallel coverage and exclusion clauses "market segmentation exclusions”: Insurance Law and Policy, 2d ed. (New York: Aspen, 2008) at 466-67.

87 Derksen, supra note 36 at para. 49. 
private insurance contract, the automobile insurance was Ontario's standard, governmentcontrolled insurance form. Yet the public nature of the automobile insurance played no overt role in the rhetoric behind the interpretation of insurance coverage in the decision. The first ramification of this purely contractual model of interpretation is that the commercial liability policy was the only possible source of recovery for income loss to compensate these children, who could not work again due to disability. The provincial automobile insurance regime in place in Ontario at that time barred recovery for the economic losses of the injured children as part of the no-fault insurance plan in place. ${ }^{88}$ So, if the commercial liability policy was not triggered, the children were unable to recover a significant component of their damages.

The second ramification is even more insidious: the decision does not appear to account for the perverse effects of off-loading risks from one insurance source to another if both policies utilize the same language for coverage grants and exclusion clauses. Here, the "use or operation of an automobile" coverage clause in the automobile insurance policy was used verbatim as the exclusion clause for the commercial liability policy. A narrow interpretation of the automobile coverage clause leads to either one of two outcomes: an off-loading of risk to the commercial liability policy or, worst of all, an inability to trigger either policy because both coverage and exclusion clauses cancel each other out. Imagine the at-fault worker's surprise when he purchased all available insurance possible to cover him for a loss, an automobile plus a commercial liability policy, and neither would cover him for this particular loss. A purely contractual model of interpretation does not prompt the court to consider the purpose behind the public automobile insurance system, how and why it is to interact with other available sources of compensation on the private market, or what the commercial effect is on the children and tortfeasor at issue if there truly was no coverage from either policy (that is, welfare for all?). This decision did not address those issues, nor did it address the future issues implicated when contests between the public automobile insurance system and various lines of private insurance utilize the same language for coverage and exclusions. Moreover, a reductionist, text-centric interpretive exercise does not assess the greater societal costs involved in a decision like Derksen regarding overlapping auto and non-auto insurance.

The haphazard mixing of interpretive models and the inconsistency in approaching various coverage-granting instruments plagues results in other kinds of insurance coverage cases as well. For example, in Somersall ${ }^{89}$ the Supreme Court of Canada used a predominantly contractual model to interpret subrogation rights as they exist in Ontario's optional underinsured motorist insurance endorsement. ${ }^{90}$ The dissent, written by Binnie J., relied on an exclusively contractual interpretive model. In Fletcher, the Supreme Court noted the public nature of Manitoba's entirely government-run automobile insurance system, but proceeded to apply a strictly contractual model of interpretation in examining the efficacy recovery of economic losses, such as income loss: see Ontario, Insurance Act, supra note 7, ss. 267(1)(2).

$89 \quad$ Supra note 11.

However, the majority decision of the Court, written by Iacobucci J., did explore a purposive view of the clause and this type of insurance, and also applied the maxim of statutory interpretation, expressio unius. 
of the form the public insurer drafted. ${ }^{91}$ Automobile insurance coverage decisions of provincial appellate courts also tend to apply a predominantly contractual model of interpretation, even when interpreting coverage-granting instruments that have statutory components. ${ }^{92}$

\section{Why The Present Interpretive Practice Does Not Work}

The present reliance on a predominantly contractual model of interpretation for automobile insurance coverage disputes simply does not work. It is reductionist and inefficient because it creates serious consistency costs, which provokes further litigation. The model is not equipped with enough explanatory power to accurately and sensibly explain what is going on in this complex commercial and very public arrangement. It also fails to consider any social context or greater impact on societal costs, despite the fact that the automobile insurance system exists as a system of public compromise, built on public values. The unique construction and regulation of Canada's various provincial automobile insurance regimes therefore calls for a unique approach to interpreting what types of accidents a provincial automobile insurance system should or should not cover.

\section{A. Consistency Costs}

The costs of inconsistency inherent in a contractual model of interpretation are enormous and unnecessary. Courts, lawyers, and litigants cannot predict an interpretive result from case to case, even if the language contained in the coverage-granting instrument is identical. ${ }^{93}$ This inconsistency greatly increases litigation costs as parties are forced to sue in order to resolve coverage disputes. In the cases discussed in this article, there is little consistency over time, despite similar repeating fact scenarios. This is all the more troubling because the provincial automobile insurance system is a controlled government effort designed to maintain an important compensation source for the public.

One source of inconsistency is the overemphasis on the form of coverage-granting instrument. If identical coverage language exists in both statutory and contractual form, there should not be different interpretations allocated to each, nor should there be differing

$91 \quad$ Supra note 35. The Court applied contra proferentem in interpreting the insurance renewal form to find that "NOT APPLIC" was ambiguous and did not inform the insured that he was not covered by underinsured motorist insurance (at 224-25).

92 See e.g. Sutherland, supra note 34 (territorial limit in underinsured motorist endorsement construed using "intention" branch of contractual model to find no coverage for accident occurring in Jamaica, despite fact that the Insurance Act was also examined); Wigle v. Allstate Insurance Co. of Canada (1984), 49 O.R. (2d) 101 (C.A.); Chilton v. Co-Operators General Insurance (1997), 32 O.R. (3d) 161 (C.A.) (applied purely contractual models for determining if underinsured motorist coverage applied for accidents involving unidentified automobile). See also Regele v. Slusarczyk (1997), 33 O.R. (3d) 556 (C.A.); Scott (Litigation guardian of) v. MacNab, [1999] O.J. No. 3260 (C.A.) (QL); Morton v. Rabito (1998), 42 O.R. (3d) 161 (C.A.) In these cases the contractual model was used to discern the definition of "automobile" in the standard provincial automobile insurance policy, despite analysis requiring navigation through statutory provisions as well.

93 It is interesting to note that nearly every major appellate insurance law decision involving the contractual interpretation of coverage is appealed to the Supreme Court of Canada by the losing party: see e.g. Bridgewood Building Corp. (Riverfield) v. Lombard General Insurance Company of Canada (2006), 79 O.R. (3d) 494 (C.A.), leave to appeal to S.C.C. refused, [2006] 2 S.C.R. ix; Progressive Homes Ltd. v. Lombard General Insurance Company of Canada, 2009 BCCA 129, 307 D.L.R. (4th) 460, leave to appeal to S.C.C. granted, [2009] 2 S.C.R. viii; Zurich Insurance v. 686234 Ontario Ltd. (2002), 62 O.R. (3d) 447 (C.A.), leave to appeal to S.C.C. refused, [2003] 1 S.C.R. xx. 
approaches to interpretation. As mentioned above, all coverage-granting instruments are provincially-regulated documents. Pretending an automobile insurance policy is a private, market-based contract existing as a bargain between insurer and insured muddles the interpretive exercise because the contractual model's tools are built around a recognition of insurers having the upper hand in drafting the coverage-granting instrument. In a monopolistic public insurance market, that is simply not the case. Insurers certainly do provide input to governments about drafting, but not to the exclusion of the governments' role in approving the various instruments in the legislative process. Creating fictions regarding the intentions of insurer and insured makes no sense when it is the legislative process that is directing mandatory public insurance. This practice perpetuates problematic, unpredictable results in insurance coverage disputes because courts treat these fictional intentions with decisive significance when explaining interpretive decisions. In reality, such relationships cannot possibly have the effect that courts pretend they do because the government charts the direction of insurance coverage.

Another source of interpretive inconsistency is the creation of artificial, extra-contractual distinctions that do not exist in the language of the coverage-granting instrument and are not buttressed by a more purposive, legislative inquiry into why such distinctions are necessary. Indeed, the Supreme Court has recently warned of the problematic nature of taking a "contextual but unprincipled approach" to insurance cases. ${ }^{94}$ For example, Vytlingam delineates a stricter causation test for automobile coverage in non-no-fault insurance coverage situations than the Amos test, which is used in no-fault accident situations. Viewed holistically, the entire panoply of coverage available in a provincial automobile insurance regime acts as a symbiotic network of compensation for injured accident victims. Treating one type of insurance as unique, absent legislative instruction, may thwart the purpose of what the system, as a system, is meant to do. No-fault accident benefits often provide only a minimum level of first party insurance. The insurance system expects the injured accident victim, in some cases, to then dip into the tort system for the greater scope of recovery that liability insurance can provide. Assuming that no-fault accident benefits are sufficient, or even appropriate, compensation is an assumption made in a vacuum. One must ask: what is the entire automobile insurance system purporting to do by having a dual tort and no-fault system? How do the two operate in conjunction? A purely contractual model does not account for such purposive examinations.

A second artificial extra-contractual distinction, also from Vytlingam, is the requirement that, to trigger any liability insurance, underinsured motorist insurance, or uninsured motorist insurance, the harm must be the result of a tortfeasor acting as a motorist. The coveragegranting instrument does not say this. All it says is that, in order to recover, an insured must suffer harm as a result of actions by an "inadequately insured motorist.” To read in, extraa contextual but unprincipled approach would render a disservice not only to the industry, but also to insured and to victims. It would lead to further difficulties in obtaining coverage and compensation. Both parties to an insurance contract are entitled to expect that well-established principles will be reflected in the interpretation and application of that contract. In this respect, another form of public interest is also at stake. For these reasons, courts must pay close attention to the structure and actual wording of the policy, read as a whole. 
contractually, that the harm must be caused by a motorist acting as a motorist is an additional element that is not part of the coverage language. ${ }^{95}$

Of course, it may still make sense to do so when one considers the function of automobile liability insurance as distinct from other types of insurance. But to read in coveragerestrictive language, as against an insured, flies in the face of the contractual model's principle that coverage clauses are to be interpreted broadly. Vytlingam seems to say that the additional requirement of the tort being committed by a motorist acting as a motorist stems from some notion of the reasonable intentions of the parties - insured and insurer. Again, even ignoring that this is a public insurance setting, it is difficult to understand how sole reliance on a contractual model produces internally inconsistent application of principles one expects to be standard. Worse still is the seemingly incomprehensible logic that a motor vehicle accident victim who purchases underinsured or uninsured motorist insurance must first look at the at-fault motorist's behaviour as a filter for coverage. Such an analysis belies moral hazard concerns - how is the insured to control risk-enhancing behaviour of someone that is not even a party to the policy? The insured is relying on her own policy. The simplest answer is that the phrase "at-fault motorist" is nothing more than a reference to who must have insufficient insurance funds. It is not a signifier to examine the at-fault motorist's conduct "as a motorist" as a coverage filter for the accident victim's own benefits they purchased.

Finally, consistency costs are inefficiently increased because the interpretive model for automobile insurance coverage is in dire need of some framework that exudes more explanatory power to accurately and sensibly explain the outcomes of cases so that future litigants can reasonably predict litigation results. In short, the precedential value of the jurisprudence would be greatly enhanced if the logic behind the decisions was evident and consistent. The greatest culprit in this type of vexing inconsistency is the use of an extracontractual causation test for coverage. The Supreme Court of Canada has twice warned of the expensive "metaphysical debates" 96 that an insurance causation analysis can bring. So it is puzzling indeed why the Court would adopt one for an insurance issue so pervasive as automobile coverage.

The "dropping off" cases are an apt example. ${ }^{97}$ Recall that, to prevail in a coverage dispute, an insured must show an unbroken chain of events leading from vehicle use to the injury. In these dropping off cases, a driver stops the car and a passenger alights. The

It is interesting to note that, in American jurisdictions, courts generally prefer to use either the purpose or causation tests (as Major J. noted in Amos, supra note 38 at para. 21), and not both at the same time, as the Supreme Court of Canada does. The American approaches generally focus on one of two methods to determine coverage: (1) is the vehicle being used for ordinary transit purposes or (2) does the vehicle being used play a causal role for some reason other than its mere operation? There is, of course, the important distinction that, in the U.S., private insurance providers dominate and there is far less public oversight and control of insurance than in Canada: see e.g. Jerry \& Richmond, supra note 30 at 974-82; Stempel, Insurance Contracts, supra note 30 at 22-80-22-82.

96 First in C.C.R. Fishing Ltd. v. British Reserve Insurance, [1990] 1 S.C.R. 814 at 823, and again in Derksen, supra note 36 at para. 36.

$97 \quad$ See e.g. Lefor, supra note 52 (coverage when young child runs out onto road as mother leaves vehicle and attempts to cross road while holding childrens' hands); Wu, supra note 52 (coverage when child dropped off and struck by vehicle); Kopas, supra note 52 (five-year-old child got out of car in parking lot and another car backed over him; no coverage as boy had reached the fence before accident and was out of vehicle); Law, Union \& Rock, supra note 43 (taxi driver was supposed to help disabled child cross the highway; exclusion in commercial liability policy did not apply as he had stopped the vehicle). 
passenger is somehow injured. Does insurance coverage for "use or operation of an automobile" attach? The cases seem to depend on such trivial events as whether the vehicle was left running or double-parked, or where the passenger walked immediately before the accident, or the time span between alighting from the vehicle and the accident occurring. In Vytlingam, the Supreme Court commented on these cases and cryptically stated that no causal link can be established if the vehicle's involvement is severable from the "real cause of the loss." ${ }^{\text {"98 }}$ Yet it offered no guidance as to how future courts are to determine what is severable or what is the "real cause of the loss."

The "projectile" cases create a similar consistency problem when a causation test is applied. ${ }^{99}$ While there was no coverage for a drive-by shooting when an assailant either steps away from a vehicle with the engine running, ${ }^{100}$ randomly shoots a victim sitting in a vehicle, ${ }^{101}$ speeds through and fires shotguns from a moving vehicle, ${ }^{102}$ or where an assailant drops boulders onto oncoming traffic, ${ }^{103}$ there was coverage where an assailant hurled a brick at the passenger of an oncoming vehicle while both vehicles were moving. ${ }^{104}$ However, in Vytlingam the Court surmised that the brick case was incorrectly decided because the tortfeasors in the projectile cases are all at fault not as motorists but as assailants. ${ }^{105}$ The Court distinguished the result in Amos, also a projectile case, where the insured suffered from a gunshot while in his van, because that case involved first party no-fault accident benefits that did not require the activities of an at-fault motorist to trigger coverage. ${ }^{106}$

Assaults are a third troubling group of unpredictable cases. ${ }^{107}$ Some courts have found that the act of driving resulted in the road rage that instigated the assault, so coverage attaches. Other courts have found that the assault is an action severable from the use of the vehicle. Apparently, if the movement of a vehicle aggravates the assault by dragging the victim, that satisfies the causation test for coverage.

Supra note 39 at para. 29.

Russo, supra note 77 (no coverage under underinsured or uninsured motorist insurance as shooting was a separate incident from use of automobile); Chisholm, supra note 48 (no coverage when insured injured by gunshots from unknown assailants who shot into his vehicle); Zukowski, supra note 79 (no access to motor vehicle accident claims fund for victims shot by robbers while victims were parked in their own driveway). But see Chan, supra note 48 (coverage for a front-seat passenger recovered for injuries suffered when struck by a brick thrown from an oncoming vehicle); Axa, supra note 48 (coverage when claimant struck in the eye with a bungee cord while tying friend's boat to a trailer); Amos, supra note 38.

Herbison, supra note 40.

Chisholm, supra note 48; Zukowski, supra note 79.

Russo, supra note 77.

Vytlingam, supra note 39.

Chan, supra note 48.

Supra note 39 at para. 31.

Ibid. at para. 15. In Amos, supra note 38 at para. 28, Major J. surmised that a truly random shooting would not be covered by first party no-fault accident benefits because the insured must somehow implicate the "use" of the vehicle.

Hannah, supra note 81 (unidentified passenger in van snatched woman's purse and accelerated; woman thrown and dragged until purse ripped; driver's acceleration caused harm and was considered "use or operation" of motor vehicle as a motor vehicle); Letkeman, supra note 80 (injuries following resisting attempt to remove driver from vehicle did not follow from unbroken chain of events from use of vehicle); Saharkhiz, supra note 51 (accident benefits coverage for taxi driver who was assaulted by passengers who refused to pay taxi fare); Beger, supra note 51 (coverage when driver assaulted after intentional collision); Itani, supra note 51 (coverage when insured, stopped at a red light, was assaulted when another driver walked over; use of vehicle created anger resulting in assault). But see Jenkins, supra note 51 (no coverage for boy pulled off stairs of school bus and beaten by other students); Tench, supra note 51 (no coverage when passenger assaulted driver who rear-ended vehicle stopped at traffic light); Duval, supra note 51 (no coverage when insured got out of vehicle to assault other driver as causation test not satisfied). 
Based on these inconsistencies, one cannot reliably predict the results of these cases over time, or even predict how a future court would decide similar scenarios. The importation of the language of tort causation further complicates matters, as it is inappropriately applied for a very different purpose in an insurance causation context, to determine coverage. ${ }^{108}$ Dividing the past into slices on a causal time continuum prompts artificial distinctions that are not predictable or defensible from case to case. Forcing courts to use a contractual model to discuss "chains" of causation and "severable" events moves courts far beyond even a contractual model of interpretation and into fiction. It is therefore no wonder that there is much litigation over the same coverage phrase in seemingly similar contexts. The current approaches to coverage interpretation fail to explain in a rational manner how and why courts decide these cases.

\section{B. THE INABILITY TO ACCOUNT FOR SOCIAL CONTEXT AND SOCIAL IMPACT}

Because the government is intimately involved as the drafter and manager of a mandatory public insurance mechanism for such a prevalent and high-risk activity as driving, this should necessarily underscore the dynamic behind solving coverage disputes. The standard form automobile insurance coverage-granting instruments regulated and controlled by government entities is something more than a standard bilateral commercial contract between two parties. It is part of an integral social safety net that attempts to balance economic feasibility with sound risk management principles for not just drivers and partner insurers, but anyone injured by an automobile accident. It is not a stretch to say that the Canadian social and employment fabric depends on a sound and solvent automobile accident compensation system. Otherwise, injured accident victims or insolvent tortfeasor drivers must rely solely on the social benefits provided by welfare and provincial disability pension plans. Therefore, to restrict the interpretation of this important public regulatory coverage-granting instrument to merely contractually-based tools is reductionist and insufficient. Most important, it offloads risks to other insurance or other parties, or leaves an injured accident victim without compensation, all with no consideration of these consequences to the larger system.

Why does the current interpretive practice utilized by courts fail in asking the bigger questions about risk management and social impact? Likely because the contractual model has little room for these questions. A hyper-literalist approach to insurance coverage interpretation focusing solely on the text of the coverage-granting instrument moves away from the social purpose of insurance to some reductionist view that this is simply contractual language that two parties are quibbling over. It thus makes the tough social and economic decisions about risk and cost sharing seem deceptively simple. The decision ceases to be one about death or injury and instead becomes a textual one which requires only a dictionary to resolve. System-wide concerns about fairness and context are absent. This is a problem because these court decisions about coverage disputes have the potential to produce disturbing artificial results that are not carefully thought through when using solely a contractual model of interpretation. 
Derksen is the classic example. There, in a concurrent causation context, the same clause that provided coverage under the automobile insurance also took away coverage for commercial liability insurance in a separate insurance policy. Yet the court did not discuss this symbiotic relationship between insurance products. In that case in particular, the fact that the injured children would receive nothing for non-pecuniary losses under the automobile coverage was key. If those children did not receive sufficient compensation from a provincial automobile insurance regime, and the commercial liability policy did not apply to pick up the excess, where would the costs be borne? Likely, the social welfare system would bear the costs for supporting three children for life. If such is to be the result (and in some cases, unfortunately, it may be the result), surely, at the very least, in a context where coverage for automobile accidents is the responsibility of the provincial government, a thoroughly canvassed examination of the consequences is necessary. After all, this is a public system. Off-loading the consequences of automobile accidents to the public purse instead of the public automobile insurance system is an expensive move that demands careful consideration.

Separate and apart from Derksen (though it is one example), every consideration of the standard automobile coverage clause "use or operation of an automobile" has the potential to affect results in corresponding cases involving that same phrase in liability insurance exclusion clauses. ${ }^{109}$ If coverage is narrowed in the automobile insurance context, is the identically-worded counterpart exclusion in other insurance policies also narrowed, such that the latter policy's coverage is broadened? What is the effect, if any, on other insurance markets? Are risks that used to be covered by automobile insurance then simply off-loaded to other liability policies? What are the consequences, especially if courts are using a purely contractual model of interpretation, for those types of policies? And, most disturbingly, are certain accidents falling through the cracks and receiving no coverage despite the presence of multiple lines of insurance appearing to cover the loss? ${ }^{110}$ Are such losses instead being inefficiently borne by insurance brokers and agents when such coverage gaps generate professional negligence claims against them?

\section{THE SOLUTION}

What is needed is a model of interpretation that reduces consistency costs, accounts for the social impact of coverage decisions, and adheres to financially viable risk balancing concepts with the interests of the public in mind. Anything that breeds consistency and predictability also aids an insurer's risk-assessment and financial goals, whether that insurer is a public insurer or a private insurer operating in a market co-opt province. The automobile insurance coverage-granting instrument is a regulatory document with a public purpose,

See e.g. Derksen, supra note 36; Law, Union \& Rock, supra note 43, concerning the exclusionary wording for automobile accidents in a commercial liability policy.

$110 \quad$ As nearly occurred in Derksen, ibid. See also Vytlingam, supra note 39 at para. 3. In some cases, courts do note some of the consequences of risk balance, but often in an incomplete fashion. Nor do they assess the full social cost impact. In Vytlingam, for example, Binnie J. noted that the plaintiffs were paid in excess of $\$ 1$ million in no-fault accident benefits from their own insurer. This was to compensate for losses of the insured, his mother, and his sister. He goes on to note that the damages suffered by the insured alone were $\$ 960,765.70$, plus post-judgment interest. Yet he makes no further use of this information, which seems to suggest that the insured alone received less than 50 percent of the compensation he required. 
acting as a necessary piece of the provincial accident compensation web. ${ }^{111}$ This is so regardless of whether the insurance coverage-granting document exists as a statute, a regulation, or as a private contract approved for sale by the provincial government. Yet, at the same time, the document is also drafted with varying degrees of input from the private insurance industry who, in the majority of provinces, are charged with selling the insurance products and paying the accident claims. The coverage-granting instrument is not, then, solely a creation of legislative action. An interested private party, the insurer, has an input role in this regulatory instrument with a public purpose. The other interested party, who has no individual involvement in the drafting of the document, ${ }^{112}$ is the insurance customer who purchases the various provincially-mandated and approved insurance products. Driving customers have little consumer choice and are not able to bargain with either the insurer or provincial agency about the major terms of their mandatory automobile coverage. Therefore, because the automobile insurance coverage-granting document is a public regulatory document drafted with some assistance from the insurance industry, any interpretation of the limits of that coverage-granting document must account for the document's hybrid status.

\section{A. THE SPIRIT OF THE SOLUTION}

The interpretive model should combine the best of the legislative and contractual models of interpretation, but hold fast to the notion that automobile insurance exists as a public regulatory document with a public purpose. Jeffrey Stempel has argued that the interpretive exercise common in disputes about the scope of insurance coverage would be greatly enhanced if insurance were thought of not merely as a private contractual agreement, but instead as a statute. ${ }^{113}$ Stempel notes the similarities between the drafting of statutes and the legislative-like process of the insurance industry drafting standard form insurance contracts. The interpretive exercise of discerning the limits of insurance coverage should be informed by canons of statutory construction, according to Stempel, so that a more comprehensive set of interpretive tools, beyond the standard text-based insurance contract tools, would be regularly deployed in difficult coverage disputes. Courts should look to the drafting intent of insurers, take a purposive approach to interpreting coverage-granting instruments, and examine the drafting history of insurance policy language. This would ensure a more comprehensive and fair interpretation as to what the coverage-granting instrument is trying to do. The text-centric interpretive tools for standard insurance contracts would be elevated to a more robust analysis.

Second, Stempel also argues that all insurance is a social institution for distributing losses in society, and that any attempts to interpret insuring agreements should bear in mind that integral social purpose, and thus shy away from an overly slavish text-driven approach to interpreting language in insurance policies. ${ }^{114}$ Stempel suggests that courts interpret insurance coverage-granting instruments with an eye to what the insurance instrument's larger social

Along with provincial disability insurance pensions, workers' compensation regimes, welfare and social security, and health care.

112 Though, arguably, one would think that the legislative process represents the interests of members of the public affected by the insurance regime.

113 Jeffrey W. Stempel, "The Insurance Policy as Statute” (2010) 41 McGeorge L. Rev. 203 [Stempel, "Insurance Policy as Statute"].

114 Jeffrey W. Stempel, “The Insurance Policy as Social Instrument and Social Institution” (2010) 51 Wm. \& Mary L. Rev. 1489. 
policy goals are supposed to be, and how granting or refusing coverage would frustrate that goal. Like treating insurance as a statute for the purposes of interpretation, Stempel's notion also calls for an augmented purposive examination of the extra-textual circumstances behind insurance coverage-granting instruments.

Yet insurance, even public insurance, exists as a product of the market. Consumers purchase this product and, in many provinces, insurers compete for business. Daniel Schwarcz has posited that insurance policies should best be thought of as products on a consumer market, and insurers should be liable for deficiencies in these products just as manufacturers are liable for dangerous goods they place on the market. ${ }^{115}$ Consumers need protection from deficient insurance products and insurance law should be responsive to this need. Indeed, Craig Brown has commented that all insurance law is, in essence, really about consumer protection. ${ }^{116}$

How, then, should the Canadian interpretive framework for insurance coverage disputes proceed? Stempel's notions of insurance as statute and insurance as a social institution are written in an American context, where the primary modality of automobile insurance provision is the private insurance market. ${ }^{117}$ Although there are varying levels of governmental control with respect to auto insurance, no state's system rises to the same level of intense regulation and governmental involvement as exists in Canada. Therefore, Stempel's public-centred ideas are well suited to the monopolistic, government-mandated automobile insurance system found in Canada. Also, inherent in both Canadian models of interpretation - the contractual and the legislative models — is a certain degree of consumer protectionism. A public automobile insurance system needs to protect the public. This notion is certainly applicable when one sits down to interpret coverage instruments, and should be maintained in the framework. Canadian automobile insurance exists in its present form because its role as a social institution has been realized as a necessary public good. Therefore, any attempts to determine how and when automobile insurance coverage applies in an accident situation needs to account for the unique role of automobile insurance within the fabric of Canadian society. It is a contract subject to more than the private, contractual principles of interpretation; it is a social contract, closer to statute than private commercial agreement. $^{118}$

Daniel Schwarcz, “A Products Liability Theory for the Judicial Regulation of Insurance Policies” (2007) 48 Wm. \& Mary L. Rev. 1389.

116 Brown, "Private Insurance," supra note 4 at 275.

117 However, the same conflicting litigation about the same coverage disputes occurs in the U.S.: see Stempel, Insurance Contracts, supra note 30 at 22-80, n. 213 (noting that there is a great deal of litigation when a loss is produced by something other than a typical car crash); Peter Nash Swisher, "Judicial Rationales in Insurance Law: Dusting Off the Formal for the Function" (1991) 52 Ohio St. L.J. 1037 at 1067 (the difference about the causal connection required in the "use or operation of an automobile" coverage cases is often the difference between a formalistic (contractual) and functional (legislative) approach taken by courts); Peter Nash Swisher, "Judicial Interpretations of Insurance Contract Disputes: Toward a Realistic Middle Ground Approach" (1996) 57 Ohio St. L.J. 543 at 629 (noting the confusing differences among courts interpreting automobile insurance coverage language, where ambiguous facts may drive results, such as the speed of the vehicle helping to determine projectile injury cases).

118 Indeed, Stempel advocates an interpretive regime based on statutory interpretation principles for this very reason: Stempel, "Insurance Policy as Statute," supra note 113 at 256. Marvin Baer has also noted the inherent governmental involvement in Canada's insurance system, and argues that this has not been given sufficient consideration in the persistent adoption of the contractual model of interpretation for coverage disputes: "The Reasonable Expectation of Unfair Exclusions in Insurance Contracts” (1998) 29 Can. Bus. L.J. 438 at 449. 


\section{Step OnE: Public PuRPose}

The first step in solving automobile insurance coverage disputes should be to discern the public purpose of the coverage-granting instrument as a whole, without regard to differentiating in what format the coverage-granting instrument exists. It should not matter whether it is a statute, a regulation, or in the form of a government-approved contract resembling a private insurance policy. It is a public document.

To determine the public purpose of the instrument, one must ask: what is the instrument trying to do on behalf of the public? What is the particular clause within the instrument trying to do for the public? Is the purpose to provide financially viable no-fault accident benefits to the driving public, in exchange for some reduction in rights to sue in tort? Is it trying to ensure that people injured by an unidentified automobile are not left without compensation merely because the at-fault motorist drove away? The public purpose of the coveragegranting instrument will ground the rest of the inquiry, and each subsequent step should always make reference to the defining public purpose of the coverage grant.

\section{STEP TWO: INTENT}

The second step is to discern the intent behind the particular coverage clause at issue. ${ }^{119}$ What were the drafters and legislature trying to do by employing the language and placement of the wording as they did? Here, it would be important to lead evidence of legislative and drafting history and background, as well as any regulatory opinions, or submissions to governmental bodies. The key is to determine the specific goal that a particular clause is supposed to accomplish. Perhaps the language used fails to clearly communicate the intent behind the clause. Evidence of drafting intent from both governmental and insurer sources would be invaluable to explaining why those specific words were chosen.

The key inquiry would be - was the use of the automobile inherently tied to an increased risk that the accident would occur? If the risk of the accident is augmented or reduced by driving-related activity, publicly-regulated automobile insurance is likely the appropriate insurance to cover the loss. Was the use of the word "automobile" also supposed to provide coverage for accidents involving backhoes and go-karts? Was the inclusion of the word "ownership" in a coverage clause meant to indicate that coverage is to attach any time an owner has a mishap with a vehicle? An inquiry into the specific drafting intent can provide extremely useful insight into why particular clauses are worded as they are. To view the wording as sui generis is reckless when, in a publicly-regulated automobile insurance system, evidence of intent is often readily documented and available. ${ }^{120}$

This is a factor that Baer has noted would be particularly helpful in deciding coverage disputes, particularly for automobile insurance in a government-controlled Canadian context: ibid. at 449-52.

However, it is acknowledged that discerning legislative intent is not always easy: see e.g. Vollick $v$. Sheard (2005), 75 O.R. (3d) 621 (C.A.) [Vollick] (vicariously liable employers are not protected defendants under Ontario's automobile regime despite statutory direction). This is precisely why this second step of interpretation needs to consider legislative drafting history, submissions to government, and regulatory opinions beyond the statutory text to discern evidence of insurer and government drafting intent in keeping with the overall public purpose of the coverage-granting instrument. Such did not happen in Vollick. 
A court must be cautious to target the correct intent behind the drafting that transcends any subsidiary intents based solely on political capture on the part of the insurance industry. The correct intent must be the public interest intent linked to the efficacy of the public automobile insurance system. This primary intent may need to be separated from other tangential intents of certain automobile insurance coverage provisions. For example, while lower or stable automobile insurance premiums and cost savings in administration may be discernable intents behind certain automobile insurance reforms, such intents are tied more to insurer cost saving than to the primary systemic goal of administering a public-centred, driver-funded compensation pool for accident victims. It is for this reason that step one of the inquiry forces the court to orient itself first toward the "public" purpose of the particular instrument. That public purpose should inform the subsequent steps, including the search for drafting intent. In step two, public interest trumps private interests.

\section{STEP THREE: CONSEQUENCES OF COVERAGE}

Armed with a solid notion about the public purpose of the particular coverage-granting instrument and the intent behind its drafting, the third step involves determining the real public consequences of granting or withholding coverage. Courts need to ask who the denial or granting of coverage affects, and how? How does a denial of coverage affect the insured and the insured's family, the insurer, other insurers who may be called upon to respond to the loss, brokers and agents who may be called upon to respond to the loss, and the efficacy of the public system? Will the insured be relegated to accepting social welfare benefits if this automobile insurance is the compensation of last resort? Will insurers, both private and public, be forced to saddle risk that is more appropriately borne somewhere else, or simply inappropriate in a public automobile insurance regime?

Moreover, a court needs to analyze the effects of a coverage decision on other insurance contexts. Is the same coverage clause used as an exclusion clause in other policies, as is the case in liability policies in Derksen, for example? How does a coverage decision affect the interpretation of similarly worded exclusionary clauses? Who is in the best position to bear these costs in a publicly administered automobile insurance system? Will insureds fall through the cracks and be left without any insurance in other contexts? Will the loss be borne by insurance agents and brokers who would be new targets for litigation resulting from insurance gaps? Will employers be unfairly saddled with the costs of accommodating the injured who are left without compensation? Is it a just and rational off-loading of risk if the compensation is left to either other insurance policies and insurers or the social welfare system to fulfill?

Finally, a court needs to be mindful of whether or not the public purpose of a particular automobile insurance policy is being achieved if the result is a denial or granting of coverage. Will too many receive compensation, stretching the system beyond capacity? Is the balance between commercial efficacy of the system and a compensation network for the injured being maintained? 


\section{STEP FOUR: CONSUMER PROTECTION}

Finally, once a court has examined the purpose, intent, and consequences behind a decision - the more systemic concerns - it may then move to a slightly more textual approach, safe in the knowledge that whatever decision it comes to will be informed by the broader public context of what the particular clause in issue is trying to achieve. For this final step in the analysis, a court should maintain the spirit of consumer protection that is inherent in present insurance law doctrine, and to a lesser degree in the legislative process. If, by this point in the analysis, it is not clear what is the most just interpretation of the clause, while keeping its public purpose in mind, a court should resort to consumer protectionist tools to resolve the analysis, but always with reference to the information gleaned from the three prior steps.

With the purpose, intent, and consequences of the public regulatory document clearly before a court, it should then embark on an interpretive exercise that invokes time-tested consumer protectionist insurance law concepts:

(1) construe coverage clauses broadly and exclusions narrowly;

(2) construe the coverage-granting instrument contra proferentem, as against the drafter; and

(3) adhere to the commercially reasonable expectations of the insured party.

In these instances, the "drafter" is anyone other than the insured. The insured, as consumer, needs protection from whatever unfairness or ambiguity that the public drafting process has generated. There is little point in inquiring about the reasonable expectations of the parties as this does nothing more than perpetuate the bargain myth and does not assist in crafting a solution mindful of the public concerns and the public rationalization. The "public" is the party of concern in this analysis. Therefore, the reasonable expectations of the insured party should be the driving force behind the interpretation at this stage. That was Robert Keeton's premise behind suggesting the reasonable expectations doctrine in the first place: a check and balance on the consuming public's interests. ${ }^{121}$ To inquire about the reasonable expectations of the insurer or government in a public automobile insurance setting therefore cannot achieve the interpretive effect that the doctrine itself is supposed to have. Indeed, in its present permutation as part of the contractual model of interpretation, the reasonable expectations step has never once played a determinative role in any insurance interpretation decision in Canada. ${ }^{122}$ It does no more than memorialize the obvious notion that insurers prefer not to pay claims, and insureds prefer to get paid. What is the point of asking about

See Robert E. Keeton, “Insurance Law Rights at Variance with Policy Provisions” (1970) 83 Harv. L. Rev. 961 (advocating for using the reasonable expectations of the insured to guide the interpretation of insurance policy provisions, even if the end result is contrary to the language of the coverage-granting instrument). See also Kenneth S. Abraham, “Judge-Made Law and Judge-Made Insurance: Honoring the Reasonable Expectations of the Insured” (1981) 67 Va. L. Rev. 1151 (arguing that the reasonable expectations principle has significant regulatory power in deciding insurance contract disputes at a systemic level). rather limp Canadian redundancy" compared to the "aggressive American doctrine," which is actually helpful in solving coverage disputes: supra note 118 at 452. 
the reasonable expectations of both parties after an ambiguity in the language has been found when the first step in the traditional contractual model is to discern the intention of the parties? ${ }^{123}$ To treat the reasonable doctrine expectations as such is to gut its potential as a helpful tool in resolving coverage disputes. It becomes relegated to a descriptive filler only, without any teeth.

In this four-stage approach, there is no need to start with a reductionist, text-centric methodology. The prior three steps essentially make the fourth step a necessary one: if a court is still unclear about how to resolve the interpretive question, the language of the coverage-granting instrument may be of assistance, but only if informed by the information from the previous steps.

How, then, is a court to know if the interpretive question is still unclear by this stage if, despite all of this context, there arise two conflicting results that are equally defensible in the face of the public purpose of this automobile insurance provision? It is vital to focus on conflicting result, not conflicting meaning. The meaning of insurance language is often mutable, and always completely context-driven. Focusing on ambiguity of text is therefore usually fruitless. One party is always attempting to find ambiguity, while the other party is always attempting to dispel it. It is the result, memorialized in writing by the coveragegranting instrument, that this analysis should focus on in attempting to achieve the public purpose of automobile insurance.

"Use or operation of an automobile" seems to mean different things depending on whether a brick is thrown from a moving vehicle, or how a gun is shot out of a vehicle. It is the result of the interpretive exercise that interests the court and the litigants — what does it mean here and in this context? Despite courts having stated such, ${ }^{124}$ there is no insurance clause in existence that is static in meaning for all times and for all things. The meanings are as varied as human experience itself.

Why the emphasis on consumer protection in a public interpretive setting? The insured public has no ability to individually affect the operation of the automobile insurance system ex post by the time the accident has occurred. While the public can influence the legislative process in an indirect way, it is the individual insured who must bear the cost of the coverage decision, whatever it is. To that end, tensions between the public purpose of a particular coverage provision and the efficacy of the insurance system as a whole (regardless of the involvement of private insurers anywhere in the process) should be resolved in favour of the individual insured. The reason is simple: the individual should not bear the cost of an ineffective public system. If the system is producing unclear interpretive results, the system needs to be fixed. Such is not the fault of the individual, nor should it be left to the misfortune of the individual. It is a failure of the imperfect public system for its inability to foresee every permutation of insurance at work. The legislative process should be triggered, post-decision, to ameliorate the interpretive confusion. Indeed, as Michelle Boardman notes,

Indeed, Billingsley alludes to the confusion about the role that intent plays in the interpretive process: supra note 37 at 141-45. See also ibid. at 441.

$124 \quad$ See e.g. Scott, supra note 35 at 1465; Eichmanis v. Wawanesa Mutual Insurance (2007), 84 O.R. (3d) 668 at 676 (C.A.) (both noting that a provision excluding criminal acts from insurance coverage is "perfectly clear and unambiguous"). 
insurance policy language is not written for consumers, but really for courts. ${ }^{125}$ Consumers should not bear the brunt of drafting failures resulting from a public process.

Therefore, adhering to the tenets of consumer protection as a final interpretive stage serves as a check and balance on the system itself; so the costs of error are borne by the public system and not by the individual injured accident victim. The system must be ever mindful that leaving an injured individual uncompensated may save the public automobile system money, but it is a cost to the other public compensation spheres of welfare, health, and disability pensions.

An example may be helpful here to illustrate the type of process envisioned in this interpretive solution. Imagine that an insured is expecting coverage for first party no-fault accident benefits from her own insurer, as well as unidentified motorist insurance coverage, because she seeks compensation for injury after she was randomly shot while sitting in her vehicle. The assailants were bank robbers and the insured was hit by a stray bullet while parked in the bank parking lot. The robbers drove away in an unidentified vehicle. The operative coverage provision of her insurance is contained in her provincially-approved insurance policy and provides stipulated no-fault accident benefits for accidents "arising from the use or operation of an automobile.” It also provides additional coverage when an accident is the result of "use or operation" of an unidentified vehicle. Should she expect coverage?

Step one of the solution seeks to determine the public purpose of the coverage. Here, the no-fault accident benefits coverage is designed to compensate the insured for accidents arising out of the use of a motor vehicle, without regard to fault of the insured or the tortfeasor. It provides for lower benefits than an insured would normally be entitled to under the tort system, but does not require proof of fault. The unidentified motorist insurance coverage is a replacement for liability insurance. It is designed to assist injured insureds who have had the misfortune of being involved in an accident that would have been recoverable under tort from the perpetrator's third party liability insurance had the perpetrator not fled. It essentially stands in the shoes of the perpetrator's third party liability insurance to compensate the injured first party insured. Under this coverage, benefits are only limited by what is recoverable in tort, but the negligence of the unidentified third party driver is the trigger for compensation.

Step two attempts to identify the intent behind the particular automobile insurance coverages. The legislative and drafting history would be key here, as well as any submissions from the insurance industry to the relevant insurance-governing provincial ministries. This type of evidence would likely show that the intent of the coverage clause for no-fault accident benefits was to provide broad-spectrum coverage for the risky activity of driving. Because the scheme covers even pedestrians and cyclists who are injured by driving activity, automobile "use" is not restricted to two-car accident situations. The system, which is underwritten by the premiums paid by drivers, is targeting the serious societal cost of driving-related risks. It is neither health nor crime insurance. 
The intent of the unidentified motorist insurance is likely to insure that innocent accident victims are not left without compensation merely because they had the misfortune of being involved in a hit-and-run accident. Like no-fault accident benefits coverage, this coverage is also targeting the risks of driving but is more tailored to the specific risk of an accident victim being unable to claim in tort for something she normally would, and which is beyond her control. If the victim would normally be able to claim in tort against the third party were they to be identified, the uninsured motorist coverage should be triggered.

Should a public, no-fault accident benefits scheme cover this type of loss? There is nothing driving-related about the accident that befell the unfortunate insured. The risks inherent in the situation are not augmented or reduced because of her driving activity. She did not have to be in a vehicle to suffer this injury. Most important, a shooting is likely not the type of risk targeted by the public automobile insurance system. This system was not designed to provide compensation for injuries resulting from the discharge of firearms. Misuse or use of an automobile does not alter the risk in this situation.

Should the unidentified motorist coverage respond to the loss? If it is in keeping with the purpose of this coverage, a court should then ask whether it is appropriate for the accident victim to be able to recover in tort under a liability policy as if the vehicle were identified. If liability insurance would have been triggered for legal liability arising from "use or operation" of the assailant's automobile, then the insured should be able to trigger her unidentified motorist coverage. The same reasons that no-fault accident benefits would not apply to this situation also apply to a denial of coverage under the unidentified motorist coverage. Parking at a bank and being in one's vehicle when unfortunate injurious events occur is not the public risk being underwritten. The public risk that is being underwritten is harm to others as a result of vehicular use and operation. Using the vehicle, from either the insured's or the assailants' perspectives, alters neither the risk of the shooting nor the end result.

Step three examines the consequences of coverage or no coverage. If there is no coverage for this loss under either policy, where is the insured to turn? There may, perhaps, be a third party liability insurance policy at the bank. The accident victim could then sue the bank in tort in the event that the bank's negligence somehow exacerbated the risk during the robbery. Such a claim would not be excluded from the market segmentation clause excluding automobile use and operation from the bank's liability policy. Barring that, criminal injuries compensation tribunals are specifically designed to respond, albeit in a modest way, to injuries from crime. The public trade-off here is that the automobile insurance system, and the risk pool of premium-paying drivers, underwrites shootings any time a vehicle is somehow in the factual nexus. If vehicle use does not alter the risk of the occurrence of this specific type of shooting injury in any fashion, it is not properly in the public risk pool managed by the system.

By this point in the analysis, there is little to be gained by invoking step four. The consequences of a denial of coverage to the public regulatory system of automobile insurance are evident. There is a just reason for not allowing coverage for this type of shooting event. Note that, by not couching the analysis in confusing terminology borrowed from tort causation to discern the meaning of the coverage clause, the analysis maintains a more 
systemic risk-balancing approach that is in keeping with public insurance goals. It provides greater direction to future courts facing similar types of accidents. It also leaves open the possibility that an accident which involves greater use or operation of an automobile in its result may attract coverage.

A second example demonstrates the importance of examining the insurance consequences that are key to step three in the analysis. Imagine a babysitter is planning to take a toddler for a ride in a vehicle. She straps the toddler into the car seat and then runs inside the house to take a phone call. She is on the phone for some time, and loses track of the time. It is an extremely hot day and the child in the car suffers serious injuries from the heat. The parents, on behalf of the toddler, sue the babysitter in negligence. Should her third party automobile liability insurance, which covers her for liability arising from "use or operation of an automobile,” respond to the claim?

Step one of the analysis is straightforward - the purpose of the insurance coverage is to provide compensation for injuries or death arising from the risky automobile use of third parties, using the at-fault tort system as a trigger of coverage. The intent inquiry in step two would focus on why third party liability insurance is mandatory for all drivers, and to what types of situations the legislature intended this type of coverage to attach. Did vehicle use augment or reduce the risk that the accident would occur? Is strapping a child into a car seat and leaving the child in a hot car "use or operation of an automobile"? At first glance, it is hard to imagine it is anything else. It is tempting to utilize a causal analysis, which traces the automobile "use" and its causal involvement in the accident. For example, is it probative that the babysitter did not start or move the vehicle, or left the vehicle? However, that detracts from the purposive analysis based on legislative intent and risk balance in a publicly operated system. A causation-driven analysis also introduces myriad inherent hairsplitting exercises in chasing unhelpful chains of causation.

The end result is that the child was injured in a vehicle that was being readied to be driven. The child could not get out of the vehicle and the very nature of the vehicle was what put him in the risky situation that resulted in injury. Is this the type of risk to which a public automobile insurance system that mandates third party liability coverage for all drivers is expected to respond? Did the insured babysitter "use" or "operate" her vehicle, and did that use or operation generate the legal liability that she now faces? The vehicle use augmented the risk that the accident would occur; in fact, its use made the very accident possible. Consider that there is regular coverage for pedestrians injured by automobiles. Consider further that there is often coverage found where the injured victim is hurt by some aspect of vehicle use that does not immediately involve driving, but can only be described as "use." For example, if a pedestrian walks into a pole protruding from a truck, there is coverage. ${ }^{126}$ There is also coverage if a person suffers psychiatric injury as a result of a vehicle crashing into the person's house. ${ }^{127}$ These are events by which driving activity and vehicle "use" increases the risk of their occurrence, and for which mandatory public automobile liability insurance ought to respond. insurance). 
Step three, the consequences analysis, is important. Here the type of insurance being sought has a corollary in the private insurance marketplace, which may additionally cover the risk - homeowners' liability insurance. The market segmentation clause in the homeowners' policy would exclude loss or damage arising from "use or operation of an automobile," so that only an automobile liability policy would be expected to cover autorelated risk. If coverage is denied under the automobile policy, is it also denied under the homeowners' policy? If the coverage clause for the automobile insurance is read too narrowly, would/should other liability policies pick up that risk? Or will this perpetually lock insureds in difficult contests between two liability insurers? A court would have to determine that likelihood in this situation, given the facts and the wording of the homeowners' policy. Perhaps the losses are concurrent such that both policies respond to a proportion of the loss. ${ }^{128}$ Regardless, the presence of other insurance does not negate the inquiry into automobile insurance coverage. It simply makes the court aware of the network of compensation so that the network's efficacy can be properly balanced, and risk sensibly managed, so that losses lay where they most sensibly should. In this scenario, it is likely that the automobile insurance policy covers the loss, for the reasons stated above.

If there is any doubt about the purposive result in finding coverage for the loss, interpretive ties go to the insured. The coverage clause is to be read broadly and in keeping with the reasonable expectations of the insured party. A reasonable insured would expect automobile insurance coverage in an accident involving an immobilized child in a car seat that is injured as an inherent result of its immobilization in a vehicle, which are known to heat up on hot days. If such instances were not meant to be covered by the "use or operation" coverage language, direction could have been provided in the coverage grant or exclusions.

\section{ConClusion: DefENDing THE SOLUTION}

The interpretive solution presented here is suited to predictably solving automobile insurance coverage disputes by interpreting coverage-granting instruments as public regulatory documents, with some knowledge that private insurers have varying degrees of drafting input. The solution is not a distributive model. The default rule is not always a grant of coverage. Rather, the solution forces courts to enter into a balancing exercise. The question becomes one of a justification of resources through the eyes of the public, not the insurer or individual insured. Was this public system intended to sustainably provide compensation for this type of activity? Adopting the proposed solution would lead to courts discarding the Amos purpose and causation test, and other extra-textual doctrinal tests. The solution builds in steps with greater explanatory power to improve jurisprudential value over time, for both repeat players in the system like insurers and governments, as well as consumer protection mechanisms for one-time players like injured accident victims. Courts would focus primarily on what an automobile insurance regime is supposed to be doing, and less on the intricacies of written text.

The solution should help to clarify the troublesome lines of coverage cases like the assault cases or the projectile cases, where insureds attempt to invoke automobile insurance coverage for situations other than two-vehicle accidents. Having some evidence of drafting 
intent and a purposive analysis tied to risk augmentation would go a long way towards identifying a reliable answer to many of these variable accident scenarios. Furthermore, understanding the consequences of coverage in the scenarios better informs the end result because it requires a consideration of whether or not the public automobile insurance system can and should tolerate gaps in coverage for certain situations. Finally, if in doubt, the consumer protectionist tools in step four will resolve the question in favour of the insured and hopefully prompt legislative action to clarify the interpretive confusion for future accident victims if such confusion is unsustainable by the system. Rather than relying on an unpredictable causal analysis, courts should be better equipped to articulate reasons why the public insurance regime is not meant to cover certain accidents.

The additional costs in initially implementing the new solution are soon eclipsed by the benefits of a predictable interpretive framework. For example, costs for providing evidence of drafting intent to courts should be drastically reduced over time, as a more stable body of jurisprudence should result. The off-loading of compensation from one line of insurance to another will be done with a full consideration of the entire systemic insurance context. The cost of errors in coverage decisions will also be absorbed by the insurer instead of the individual seeking coverage, which should prompt further insurance policy clarifications and redirect costs to reduce the burden on social welfare assistance in certain cases.

Finally, the solution has implications for non-automobile insurance coverage disputes as well. As the convoluted line of automobile insurance coverage cases are eventually sorted out with greater explanatory reasons and in a more predictable fashion, perhaps the contractual interpretive framework for other types of private insurance would also benefit from a more purposive and contextual approach that accounts for the pervasive role of insurance in Canadian life. Courts may be surprised to learn that there is just as much public interest driving the private, non-automobile insurance context as there is driving Canada's public automobile insurance system. Regardless, the public regulatory nature of automobile insurance in Canada deserves a consistent interpretive framework that effectively balances financially viable risk principles with public compensatory values. Auto insurance is truly a social contract. 